\title{
Advances in citrus propagation in Brazil
}

\author{
Sérgio Alves de Carvalho ${ }^{1}$, Eduardo Augusto Girardi², Francisco de Assis Alves Mourão Filho \\ Rhuanito Soranz Ferrarezi ${ }^{4}$, Helvécio Della Coletta Filho ${ }^{5}$
}

\begin{abstract}
Citriculture is an important agricultural activity worldwide, occupying a relevant position in Brazil among fruit tree production for both the fresh fruit market and the processing industry for concentrated orange juice export. Recent advances in the country's citrus nursery tree production system have been essential to guarantee the efficiency and competitiveness of Brazilian citriculture. The implementation of strict laws and regulations to produce trees in protected environments and improvements in production techniques for basic citrus propagation materials and nursery trees in São Paulo state has excluded the insect vectors of destructive diseases such as citrus variegated chlorosis and huanglongbing, making this an innovative reference system for citrus propagation around the globe. The main aspects of these advances are presented and discussed in this review, including advances in propagation techniques, scion and rootstock selection, genetic characterization and certification, tree size standards, cultural practices such as irrigation and fertilization for the production of citrus propagation materials and nursery trees, and nursery management tools.
\end{abstract}

Index: Citrus spp., basic material, nursery tree production, budwood increase blocks.

\section{Avanços na propagação dos Citros no Brasil}

Corresponding author: sergio.carvalho@ccsm.br

Received: June 21, 2019 Accepted: October 03,2019

Copyright: All the contents of this journal, except where otherwise noted, is licensed under a Creative Commons Attribution License.
Resumo - A citricultura é uma atividade agrícola de grande expressão mundial, ocupando posição de destaque no Brasil entre as frutíferas com elevado volume e valor de produção para o mercado interno de frutas frescas e para exportação de suco concentrado. Considerando as limitações de ordem técnica do agronegócio dos citros, principalmente as ameaças fitossanitárias, os avanços no sistema de produção de mudas e de material básico de citros nas duas últimas décadas foram essenciais para garantir a competitividade e eficiência da citricultura brasileira. A implementação e aprimoramento de normas e técnicas envolvendo a produção de mudas e material básico em ambientes protegidos de vetores de doenças como clorose variegada dos citros e huanglongbing no Estado de São Paulo, proporcionou o estabelecimento de um sistema produtivo de referência mundial. São apresentados e discutidos nesta revisão os aspectos mais relevantes destas mudanças, envolvendo técnicas de propagação, variedades copa e porta-enxerto, caracterização e certificação genética, legislação e manejo para produção de material de propagação e muda, bem como as ferramentas de gestão do viveiro.

Termos de indexação: Citrus spp, material básico, produção de muda, borbulheira.

${ }^{1}$ Dr., Pesquisador Centro de Citricultura "Sylvio Moreira”, IAC. Cordeirópolis-SP, Brasil. E-mail: sergio.carvalho@ecsm.br(ORCID 0000-00015617-8295)

${ }^{2}$ Dr., Pesquisador Embrapa Mandioca e Fruticultura, Cruz das Almas-BA, Brasil. E-mail: eduardo.girardi@embrapa.br(ORCID 0000-0003-4839-5227) ${ }^{3}$ Dr., Professor Universidade de São Paulo (Esalq). Piracicaba-SP, Brasil. E-mail: francisco.mourao@usp.br (ORCID 0000-0001-8950-9513)

${ }^{4}$ Dr., Professor University of Florida, Indian River Research and Education Center., Fort Pierce, FL, USA. E-mail: rferrarezi@ufl.edu ${ }^{\text {(ORCID }}$ 0000-0002-6873-7995)

${ }^{5}$ Dr., Pesquisador Centro de Citricultura “Sylvio Moreira”, IAC. Cordeirópolis-SP, Brasil. E-mail: hdcoletta@ccsm.br (ORCID 0000-0002-1382-4629) 


\section{Introduction}

The total fruit production in Brazil in 2018 was estimated in approximately 45.6 million metric tons (ANUÁRIO, 2018). This ranks the country as the third largest fruit producer in the world, behind only China and India. Orange for industrialized juice production or fresh fruit market is the largest fruit crop produced in the nation, followed by banana, pineapple, grape and apple. The orange production is currently concentrated in São Paulo (72\%), Bahia (6.7\%), Minas Gerais (6.5\%), Paraná (5.5\%) Sergipe (3.3\%), Rio Grande do Sul (2.7\%) and Pará $(1.3 \%)$. The 2017 orange harvest was 18.7 million tons in approximately 630 thousand hectares, with an average yield of $29.0 \mathrm{tha}^{-1}$ (IBGE, 2018).

According to Swingle and Reece's (1967) classification, the true citrus fruits belong to the family Rutaceae and include six genera, namely, Fortunella, Microcitrus, Eremocitrus, Clymenia, Poncirus, and Citrus, which are cultivated all over the globe, with commercial relevance in several countries on all continents (SUN et al., 2015). Citrus fruits are notable as excellent sources of vitamin $\mathrm{C}$, which are consumed in natura or processed to make juices, jellies, jams, preserves, and other types of candies. The extraction of essential oils and byproducts from citrus fruits for industrial processes, such as pulp pellets, is also commercially relevant.

Citrus has spread worldwide by sexual propagation from its center of origin in Southwest Asia, including to China, India, Vietnam, Laos, and Cambodia (KRUEGER; NAVARRO, 2007). Citrus was introduced in Brazil a few years after its discovery in the $15^{\text {th }}$ Century, and then spread to several regions within the country. The cultivation of citrus on a commercial scale dates from the $17^{\text {th }}$ Century onward, with a notable evolution in the production and export of fresh fruit beginning in the $20^{\text {th }}$ Century. Since the 1960s, this crop became one of the most important Brazilian commodities, generating revenue primarily through the exportation of frozen concentrated orange juice (NEVES et al., 2010).

The adoption of new technologies, such as production of varieties with more adaptations to various environmental stresses and better yields, and the use of advanced cultural practices related to tree nutritional, pest, and disease management were essential for the expansion of citrus cultivation in Brazil (BOTEON; NEVES, 2005). Recent advances in the cultural practices used for the production of basic citrus propagation materials and nursery trees were also essential to guarantee the competitiveness and efficiency of Brazilian citriculture over the last few decades.

The implementation of strict laws and regulations for citrus nursery tree production in protected environments in São Paulo state has excluded the insect vectors of destructive diseases, such as citrus variegated chlorosis
(CVC) and Huanglongbing (HLB), making this an innovative reference system for citrus propagation around the globe.

This review presents and discusses the main aspects of these advances, including techniques of propagation, scion and rootstock varieties, tools for genetic validation and characterization, and cultural practices such as irrigation and fertilization for the production of citrus basic materials and nursery trees.

\section{Propagation techniques}

Seed propagation: Seed propagation has been of great importance in citrus evolution and dispersion worldwide, as well as in clonal cleaning programs in several countries, including Brazil (MOREIRA; SALIBE, 1966). The weak vascularization of seed tissues allows them to be systemically filtered to remove pathogens, and nucellar embryony results in clonal plants that are identical to their female parent plant. The availability of virus-free nucellar clones of the main commercial scion varieties was essential for the 1969 implementation of the Mother Tree Program in São Paulo state (GREVE et al., 1991).

The rapid evolution of citrus clonal cleaning with the use of nucellar embryony was achieved with the development and improvement of the shoot-tip grafting technique, which allows for the recovery of healthy plants without undesirable juvenility (MURASHIGE et al., 1972; NAVARRO et al., 1975; PAIVA; CARVALHO, 1993). Shoot-tip grafting using portions larger than the meristematic apex and without the objective of cleaning has also been applied in the establishment and development of new varieties in breeding programs, including through somatic embryogenesis, protoplast fusion, and genetic transformation (CARVALHO et al., 2005).

Sexual propagation by seeds was initially the preferred method for the commercial production of citrus nursery trees. Until the middle of the $19^{\text {th }}$ Century, most Brazilian citrus orchards started from trees derived from direct seed germination (e.g., ungrafted trees) (POMPEU, JR., 2005).

Currently, seed propagation is limited to the production of rootstocks. The main desirable characteristics in the materials to be multiplied by seeds are high levels of nucellar polyembryony (directly related to the average number of embryos that can be produced per seed) and germination after prolonged storage (CASTLE et al., 1993; CARVALHO et al., 2005). A high degree of polyembryony facilitates the clonal propagation of rootstock seeds (SOARES FILHO et al., 2014). Production may also target the replacement of rootstocks in existing orchards by inarching (POMPEU, JR., 2005). This method has been successfully used for the recovery or prevention of the citrus sudden death (CSD) disease (GIRARDI et al., 2007b; RIBEIRO et al., 2014). 
Propagation by cuttings: Scions obtained by cuttings are clonal plants, meaning that they have the same genetic identity as their parental trees, and their use is considered a vegetative propagation method (ARAÚJO et al., 1999; ANDRADE; MARTINS, 2003).

The use of cuttings for citrus nursery tree production is still limited. Webber (1948) reported its use in citron (Citrus medica L.) production in Sicily, Italy. Pompeu Jr. (2005) indicated that the technique was used in Florida, United States of America (USA), to obtain 'Tahiti' (Citrus latifolia Tanaka) acid lime plants, inducing earlier production compared to that in grafted plants. Cuttings of the 'Tahiti' acid lime presented rooting success greater than 90\% under nebulization (ARAÚJO et al., 1999; PRATI et al., 1999).

The production of adventitious roots by rooted cuttings leads to the formation of plants with a more superficial root system than that observed in plants grown from seeds (CASTLE; YOUTSEY, 1977). Therefore, it is possible that such plants will be more susceptible to tip-over after planting in the field. Plants obtained from cuttings are usually smaller than those that originated from seeds. Rooted trees can also be similar to ungrafted trees in terms of their poor adaptation to different soil conditions, and present variable resistance or tolerance to abiotic and biotic factors such as water stress, salinity, and Phytophthora gummosis (WEBBER, 1948).

On the other hand, cuttings may be a good option for rootstock propagation in varieties with low numbers of seeds per fruit, such as 'Sunki' mandarin [C. sunki (Hayata) hort. ex Tanaka] (OLIVEIRA et al., 2014; SARMIENTO et al., 2016). Semi-woody cuttings of 'Swingle' citrumelo [C. paradisi Macfad. $\times$ Poncirus trifoliata (L.) Raf.] derived from juvenile material can be used to obtain rootstocks for the production of grafted trees or be used for inarching in the field (MOURÃO FILHO et al., 2009). Recently, procedures to increase propagation of rootstocks by root cuttings have been evaluated in Florida and found to propagate seedless materials or those with low seed counts, and to accelerate the production of certain rootstocks and budwood for nurseries (BEESON JR.; SILVA, 2017a; 2017b).

In vitro micropropagation: Advances in the development of micropropagation protocols to produce uniform rootstocks from parthenocarpic fruit with low numbers of seeds or low percentages of polyembryony were described by Carimi and De Pasquale (2003), Sharma et al. (2009), and Tallón et al. (2012). Although this method increases the cost of production per tree, it can guarantee uniformity and genetic fidelity, as in several other species that are already propagated by this method. The use of micropropagation at a large scale started in the 1980 s with the propagation of ornamental plants, vegetable crops, and other fruit trees (KITTO, 1997; WINKELMANN et. al., 2006).
Micropropagation has been used in citrus as an important auxiliary biotechnological tool and for the rapid multiplication of new materials with horticultural characteristics of interest (CARVALHO et al., 2005). This method was already used commercially in Brazil for the propagation of 'Sunki' mandarin in the 1980s due to its small number of seeds and low seed availability (CARVALHO, 1992).

Plants propagated by seeds, both from zygotic and nucellar embryony, present a pivotal or axial root system, with a pivotal root responsible for growth in depth (ESAU, 1977). The root system is bimorphic, consisting of a primary root and derivatives called secondary roots (CASTLE, 1980). There is a low predominance of the occurrence of a pivotal root in micropropagated plants as well as those obtained by cuttings. These plants are characterized by having a ramified and more superficial root system, with greater susceptibility to drought stress and tipping over (CARVALHO, 1992).

Micropropagation is gaining more importance due to the tendency of producers to use more compact plants at higher planting densities associated with irrigation needs, which eliminates the drawbacks of trees with shallower root systems (AZEVEDO et al., 2015). Considering the high demand for rootstock varieties with these characteristics and the difficulty of the largescale multiplication of newly introduced materials from breeding programs, the commercial production of citrus rootstocks using micropropagation has been successfully achieved in several countries by private companies (BORDAS et al., 2016).

Grafting: The great majority of commercial citrus orchards planted worldwide are propagated by grafting, and there are records of grafting occurring in São Paulo nurseries since 1912 (HASSE, 1987). There are many advantages in the use of grafting when compared to the use of seedlings, especially the reduction of the juvenile period, production of more compact trees that better facilitates harvesting and handling, and the adaptation of the plant to unfavorable soil and climate conditions (DAVIES; ALBRIGO, 1994).

Even though grafting has promoted the advancement of commercial citrus production in Brazil, few improvements in the technique have been reported in recent years. In general, grafting in citrus results in a high yield, with practically $100 \%$ success when performed by bud slipping in the shape of an inverted T. Although some studies have evaluated alternatives for propagation, such as micro-bud grafting (SKARIA, 2000), apical stem grafting (OLIVEIRA et al., 2002), and even seed grafting (BAR-JOSEPH, et al., 2011), the high yield observed from traditional grafting in citrus nurseries may be one of the reasons why other methods have not yet been developed and/or widely used. However, techniques for improving conventional budding have been investigated, such as the 
use of photodegradable tape, which eliminates the need for manual tape removal after grafting and thus saves labor in the nursery (OLIVEIRA et al., 2004; HAYASHI et al., 2012).

Inter-grafting: This technique is necessary when there is incompatibility between the scion and rootstock, but the nurserymen or growers still want that specific combination. This is the case for the grafting of 'Pera' sweet orange [C. sinensis (L.) Osbeck] on 'Volkamer' lemon (C. volkameriana V. Ten. \& Pasq.), or selections of trifoliata [Poncirus trifoliata (L.) Raf.] and some of its hybrids, such as the 'Swingle' citrumelo (POMPEU JR., 2005). When needed, the production of 'Pera' trees is possible by using inter-grafting, the attachment of a 'filter' or 'sandwich' of another sweet orange graft, for example a graft of 'Valencia' between the 'Pera' and 'Swingle' (GIRARDI; MOURÃO FILHO, 2006; CARVALHO et al., 2011). Although the cost of producing inter-grafted trees is higher than that of conventional trees, this technique has made it possible to produce 'Pera' in regions with a high risk of CSD, such as in the northern part of São Paulo state and in the southern part of Triangulo Mineiro in Minas Gerais state (JESUS JUNIOR; BASSANEZI, 2004), where the use of 'Rangpur' lime (C. limonia Osbeck) as a rootstock is not recommended.

Use of nursery trees with two rootstocks: To overcome the low adaptability of 'Swingle' citrumelo in conditions of low soil moisture, nurserymen started producing trees with two rootstocks, especially those of 'Rangpur' lime and 'Swingle' citrumelo. This strategy would serve as a protection for the plants in regions potentially affected by CSD but with no need for irrigation. The 'Rangpur' lime would act as a drought tolerant rootstock and, in the event of root damage or death by the disease, the 'Swingle' citrumelo roots would continue to feed the plant (SETIN et al., 2005, 2009). The technical feasibility and scientific evidence of the validity of this practice are yet to be confirmed.

\section{Scion and rootstock selection}

Brazil is the world's largest producer of sweet oranges, with oranges accounting for $89 \%$ of the cultivated area in the state of São Paulo and southeastern Triangulo Mineiro in 2018, followed by acid limes and lemons accounting for $8 \%$, and mandarins for $3 \%$ of the area (INVENTÁRIO, 2018). There are also small areas in which 'Persian' limes, grapefruits, citrons, and kumquats are cultivated.

The number of varieties used in commercial orchards has been relatively stable over the last 50 years. The most frequently planted sweet oranges are 'Hamlin' (early maturing), 'Pera' (mid-season maturing), and 'Valencia' and 'Natal' (late maturing) (Table 1). In the case of 'Pera' sweet orange, the most widespread clone in São Paulo and its neighboring states is 'Pera IAC', which is pre-immunized against the most severe isolates of citrus tristeza virus (CTV) (MÜLLER et al., 1999; CARVALHO et al., 2015b). 'Pera D6' is usually planted in the northeastern region of Brazil (CUNHA SOBRINHO et al., 1980; PRUDENTE et al., 2004; ALMEIDA; PASSOS, 2011). The published inventory for the São Paulo and southeastern Triangulo Mineiro region indicates that more than 194 million sweet orange trees (productive and non-productive) are grown there, comprising $11 \%$ 'Hamlin', 35\% 'Pera', 27\% 'Valencia', $11 \%$ 'Natal', and 4\% 'Folha Murcha' trees, with the remaining 13\% of trees distributed among more than 15 other varieties (ESTIMATIVA, 2018).

The limited number of sweet orange varieties used in Brazil is due the focus of cultivation in this country on the juice market and the lack of better substitutes. This stable composition favors the prevalence of a limited genetic pool, inducing the potential for phytosanitary problems due to the close genetic base shared among such cultivars.

The main desirable characteristics in sweet orange varieties destined for use in industrialization (i.e. juice production) are high fruit yield and adequate juice quality (volume, color, soluble solids content, and total acidity). Varieties used for fresh fruit production must also present attractive coloration and low seed numbers or parthenocarpy, in addition to out-of-season maturation (early or late) for higher market value.

Several breeding programs around the world have sought to produce new varieties of sweet orange and other citrus species. In Brazil, improvement teams are located at the Campinas Agronomic Institute's 'Sylvio Moreira' Citrus Research Center (CCSM-IAC), University of São Paulo's School of Agriculture 'Queiroz' (ESALQ-USP), University of São Paulo's Center for Nuclear Energy in Agriculture (CENA-USP), Brazilian Agricultural Research Corporation (Embrapa), and Paraná Agronomic Institute (IAPAR).

Some new materials have been made available to citrus growers in recent years, with emphasis on sweet orange varieties, such as 'Iapar 73' (TAZIMA et al., 2000), 'Charmute de Brotas' (NASCIMENTO et al., 2005), and 'Homosassa' (CAVALCANTE et al., 2009). The navel oranges 'Navelina', 'Navelate', 'Lanelate'(OLIVEIRA et al., 2005), and 'Salustiana' (CAPUTO et al., 2012) were introduced from Uruguay by Embrapa Temperate Climate through Embrapa Genetic Resources and Biotechnology and indexed for viruses from June 1999 onward at the CCSM-IAC (CARVALHO et al., 2003).

Because of the presence of pigments that provide protection from oxidative stress, heart disease, and certain types of cancer (due to their capacity to inactivate free radicals), sweet oranges with a reddish flesh coloration have been especially recommended for consumption to 
improve human health. Among these, the 'Bahia Cara Cara' variety, which originated from Carabobo, Venezuela, and is rich in lycopene, stands out, as do other red sweet oranges and several true blood sweet oranges (BASTOS et al., 2014) with a more intense pulp and juice color provided by the high levels of anthocyanins in their flesh, such as 'Moro', 'Sanguinelli', 'Tarocco', and 'Malta Blood', which were introduced from different countries in the Citrus Germplasm Bank of the CCSM-IAC (LATADO, 2016).

One hundred and fifty-two citrus varieties were introduced in 1998 in Brazil from Italy, Corsica, Spain, and Portugal by the Bebedouro Citrus Experimental Station. The introduction and quarantine were done by Embrapa Genetic Resources and Biotechnology, and the materials were indexed for viruses at the CCSM-IAC. Among these, 'Navelina ISA-315' presents particularly good potential for cultivation due to its demonstrated resistance to CVC in the field (FADEL et al., 2014). This clone was diagnosed as harboring the viroids of cachexia and xyloporosis and having been sanitized and pre-immunized against the most severe strains of CTV (CARVALHO et al., 2003).

The 'Shamouti' sweet orange presented excellent performance in field evaluations for tolerance to the citrus canker bacterium (Xanthomonas citri subsp. citri (ex Hasse) Gabriel et al., 1989) (CARVALHO et al., 2015a). On the other hand, due to problems with blooming and fruiting in crops of this variety in the southern region of Brazil, it requires trunk girdling in the fall to achieve better performance (KOLLER et al., 2000).

In addition to the promising seedless materials obtained by mutation (LATADO et al., 2001), the adaptability of several 'Pera' sweet orange clones to different rootstocks and climates has also been indicated in studies done in the states of Paraná and São Paulo (TAZIMA et al., 2010; MAIA et al., 2013; CARVALHO et al., 2015b).

New introductions of mandarins and hybrids have led to the dissemination of new cultivars in Brazil. This is important for the diversification of varieties in Brazil, since this market is still dominated by the 'Ponkan' mandarin (C. reticulata Blanco), followed by small proportions of the 'Murcott' tangor [C. sinensis (L.) Osbeck $\times C$. reticulata Blanco], 'Cravo' mandarin (C. reticulata Blanco), and 'Do Rio' and 'Montenegrina' mandarins $(C$. deliciosa Ten.) (PIO et al., 2005). Although 'Ponkan' is preferred by the Brazilian consumer, it is problematic for commercialization due to its high numbers of seeds and short post-harvest conservation period. New materials indexed for viruses introduced from the CCSM-IAC's Citrus Germplasm Bank have been evaluated, and as a result, the 'Fremont' $(C$. clementina Hort. ex Tan. $\times C$. reticulata Blanco) and 'Thomas' mandarins (C. reticulata Blanco) have already been released (AZEVEDO et al., 2010; BASTIANEL et al., 2014; PACHECO et al., 2017).
The 'Murcott' tangor hybrid has also been gradually replaced by other cultivars that are equally productive and more resistant to the Alternaria brown spot disease (Alternaria alternata f. sp. citri), a disease with high control costs. Originally from Morocco and introduced in California, USA, in 1985 as 'W Murcott', the 'Afourer' tangor, also known as 'Nadorcot' (NADORI, 2004), produces seedless fruits with earlier maturation than those of 'Murcott'. In 2000, through the Florida Department of Agriculture and the Campinas Agronomic Institute's Quarantine Center, this variety, which had been micrografted and pre-immunized, was introduced in Brazil by the CCSM-IAC and registered at the National Register of Cultivars (RNC) of the Brazilian Ministry of Agriculture, Livestock, and Food Supply (MAPA) as 'IAC 2013 WM'.

The 'Dekopon' hybrid, a seedless variety obtained from the crossing of 'Ponkan' mandarin (C. reticulata Blanco) with 'Kiyomi' tangor [C. unshiu Marcow x $C$. sinensis (L.) Osbeck], was developed in 1972 in Nagasaki, Japan. This variety is known as 'Shiranui' in Japan, 'Sumo' in the USA, and 'Kallabong' and 'Jallasan' in South Korea (OLIVEIRA et al., 2012). This variety was introduced in Brazil in the 1980s and indexed and micro-grafted at the CCSM-IAC, and was registered at the RNC of MAPA as 'IAC 2009 Dekopon'. It is cultivated by citrus growers from Pilar do Sul, São Paulo (SP), who are members of the São Paulo State Association of Persimmon Producers, and it was renamed 'Kinsey' mandarin in November 2007.

'Nova' tangelo [C. Clementina Hort. ex Tan $\times(C$. paradisi Macf. $\times$ C. tangerina Hort. ex Tan)], 'Ortanique' tangor [C. sinensis (L.) Osbeck $\times$ C. reticulata Blanco], 'Clemenules' and 'Marisol' clementines (C. clementina hort. ex Tan), and 'Satsuma Okitsu' (C. unshiu Marcow) clementines were introduced from Uruguay via Embrapa Genetic Resources and Biotechnology, indexed at the CCSM-IAC (CARVALHO et al., 2013), and evaluated under different edaphoclimatic conditions (BORGES; PIO, 2003; SORRENTI et al., 2008; CANTUARIASAVILÉS et al., 2010; TAZIMA et al., 2015). They are currently recommended as apyrenic cultivars of citrus fresh fruit by Embrapa Temperate Climate and partner institutions for use in southern Brazil (OLIVEIRA et al., 2005; BORGES et al., 2009). In the northeastern region of Brazil, the 'Piemonte' tangor [C. clementine hort. ex Tanaka $\times(C$. sinensis L. Osbeck $\times C$. reticulata Blanco $)]$ has been presenting good fruit production with high quality, even in tropical climate conditions (CARVALHO et al., 2016a). More recently, the cultivar 'IAC 2019Maria', which originated from a cross between 'Murcott IAC' and 'Pera IAC' and has fruit similar to those of the 'Murcott' tangor but maturing earlier (between April and June), was the first citrus cultivar from the Campinas Agronomic Institute protected under the National Service of Cultivar Protection of MAPA (CRISTOFANI-YALY, 2017). 
Table 1. Maturation time of sweet oranges, mandarins, acid and sweet limes, lemon and grapefruit cultivars cultivated in Brazil.

\section{Sweet oranges}

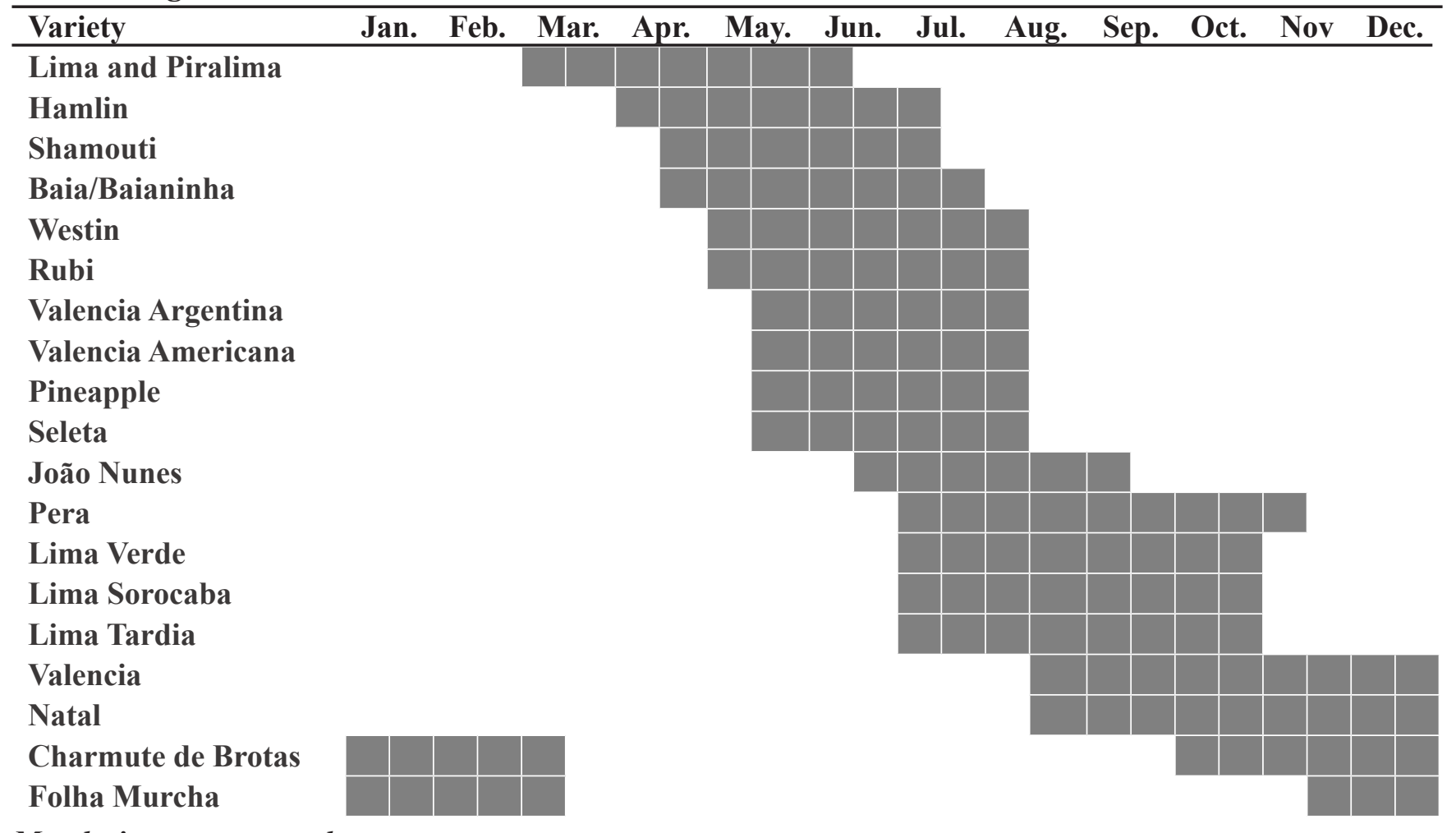

Mandarins, murcots and tangors

Variety

Jan. Feb. Mar. Apr. May. Jun. Jul. Aug. Sep. Oct. Nov Dec.

Ponkan

Mexerica-do-Rio

Cravo Tangerine

Clementina

W Murcott Tangor

Dekopon Tangor

Montenegrina murcot

Murcott Tangor

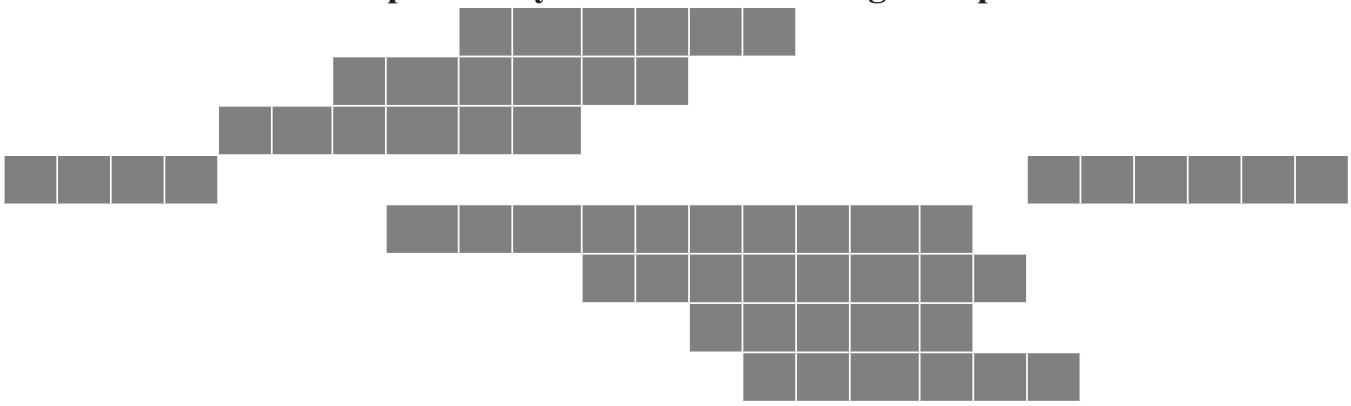

Sour and sweet limes, lemon and grapefruit

Variety

Galego Acid lime

Tahiti Acid lime

Pérsia lime

Sicilian lemon

Marsh Seedless grapefruit

Jan. Feb. Mar. Apr. May. Jun. Jul. Aug. Sep. Oct. Nov Dec.

Source: Adapted from Pio et al. (2005) 
Among the acid limes, the Mexican lime variety, known in Brazil as 'Galego' [C. aurantiifolia (Christm.) Swingle], has a limited market. The most cultivated variety is the 'Tahiti' lime. The most prevalent clone of 'Tahiti' lime in São Paulo is 'IAC 5' (also known as 'Peruano'), which is of nucellar origin (FIGUEIREDO, 1991). This clone was later submitted to clonal cleaning and preimmunized against the most severe isolates of CTV and named 'Tahiti IAC 5-1' (CARVALHO et al., 2001a), and then became the most widely cultivated clone in São Paulo state. The 'CNPMF-1' and 'CNPMF-2' clones of 'Tahiti' lime are more common in the northeastern region of Brazil (PIO et al., 2005). Even though legislation prohibits the delivery of trees contaminated with citrus diseases by nurseries since diseased plants are smaller and induce outof-season fruiting compared to that of healthy trees, 'Tahiti Quebra-Galho' is still cultivated in São Paulo and other states, despite it being contaminated with citrus viroids $(\mathrm{CVd})$, including those of citrus exocortis (CEVd) (PIO et al., 2005). Recent studies indicated the potential of new 'Tahiti' acid lime cultivars to achieve high productivity in both irrigated and non-irrigated orchards in São Paulo and
Bahia states, including such nucellar clones and accesses introduced from other countries as 'BRS Ponta Firme', 'CNPMF-01', 'CNPMF-02', 'Persian-58', and '5059' (BREMER NETO et al., 2013; SANTOS et al., 2016).

The true lemons [C. limon (L.) Burm. f.] most frequently cultivated in Brazil are of the 'Eureka', 'Femminello', 'Lisboa', and 'Genova' varieties, for which the Sicilian synonymy is generally used, alluding to the origin of the first lemons introduced in the country from Sicily, Italy (POMPEU JR., 2005).

Regarding the varieties used as rootstocks, the use of 'Rangpur' lime has been predominant since the citrus tristeza virus outbreak in the late 1930s and has mainly been used to produce viroid-free sweet orange nucellar clones. The reasons for this include this variety's rusticity, resistance to drought, and vigor in the nursery and in the field, as well as the precocity of its fruit production and its high productivity (POMPEU JR., 2005). However, as a result of CSD (INFORMATIVO, 2001; MACCHERONI et al, 2005), a significant change in the scion/rootstock combinations used occurred, with the occurrence of 'Swingle' citrumelo becoming higher (Table 2).

Table 2. Rootstock cultivars used in the production of citrus trees in nurseries of the State of São Paulo, from 1970 to 2000 (POMPEU JR. (2005), 2009 to 2015 (POMPEU JR. \& BLUMER, 2016) and in 2016 (SETIN, 2017).

\begin{tabular}{lccccccc}
\hline \multicolumn{1}{c}{ Rootstock } & $\mathbf{1 9 7 0}$ & $\mathbf{1 9 8 8}$ & $\mathbf{2 0 0 0}$ & $\mathbf{2 0 0 9}$ & $\mathbf{2 0 1 4}$ & $\mathbf{2 0 1 5}$ & $\mathbf{2 0 1 6}$ \\
\hline & & \multicolumn{7}{c}{$(\%$ total plants $)$} \\
Rangpur lime & 99.1 & 65.0 & 74.9 & 48.0 & 53.0 & 35.0 & 33.0 \\
Swingle citrumelo & 0.0 & 0.9 & 6.0 & 25.0 & 32.0 & 39.0 & 50.0 \\
Cleopatra mandarin & 0.3 & 27.7 & 13.7 & 15.0 & 1.6 & 1.2 & 1.2 \\
Sunki mandarin & - & 1.3 & 1.1 & 4.9 & 10.4 & 3.8 & 11.9 \\
Volkamer lemon & - & 0.7 & 1.0 & 2.4 & 0.7 & - & - \\
Poncirus trifoliata & 0.2 & 0.7 & 2.3 & 3.8 & 1.4 & - & 3.8 \\
\hline
\end{tabular}

In 2015 , the percentage of rootstock varieties used in São Paulo orchards was $46.2 \%$ 'Rangpur' lime, $19.4 \%$ 'Swingle' citrumelo, $4.6 \%$ 'Sunki' mandarin, and $2.5 \%$ 'Cleopatra' mandarin (C. reshni hort. ex Tanaka) (POMPEU JR.; BLUMER, 2016). However, this distribution tends to change over time, with the use of 'Swingle' citrumelo likely to surpass that of 'Rangpur' lime in the near future. In 2016, 50\% of the approximately 10.5 million nursery trees produced in São Paulo nurseries were grafted on 'Swingle' citrumelo, with only 33\% grafted on 'Rangpur' lime (Table 2). There is also more use of $P$. trifoliata hybrids in comparison to that in previous years, which is probably due to the expansion of the trifoliate dwarfing variety 'Flying Dragon' $[P$. trifoliata var. monstrosa (T. Ito) Swingle], especially as a rootstock for the 'Tahiti' acid lime (CANTUARIAS-AVILÉS et al., 2012; ESPINOZA-NUÑEZ et al., 2011; STUCHI et al., 2003).
It is also important to mention that other studies evaluating disease-tolerant rootstocks with lower irrigation demand also have a smaller canopy size, increasing the efficiency of production per canopy volume (POMPEU JR., 2005). This strategy has been adopted in recent years due to the increased frequency of the HLB disease. Technologies that include the production of smaller trees and use of increased planting densities have been investigated in other countries to compensate for the eradication of infected plants and maintain productivity. Among other strategies for reduction in tree size, the use of viroids, 'filters', and 'inter-grafts' can be mentioned (SALEH et al. 2008; HUSSAIN et al., 2012). Genetic improvements to obtain materials that have reduced canopy sizes, especially tetraploid rootstocks, have also been sought (BRUYERE et al., 2016). 
Studies seeking to increase the diversification of rootstock varieties indicated the great potential of using 'Sunki Tropical' mandarin (SOARES FILHO et al., 2002), citrandarins and trifoliate hybrids (BLUMER; POMPEU JR., 2005; CRISTOFANI-YALI et al., 2007; RAMOS et al., 2015; CARVALHO et al., 2016b; FRANÇA et al., 2016), and the 'F80' citrumelo and other trifoliates (POMPEU JR.; BLUMER, 2005). The performance of several new rootstocks and their combination with different varieties under nursery conditions was reported by Schinor et al. (2015), Rodrigues et al. (2015, 2016), and Parolin et al. (2017).

\section{Characterization and genetic certification}

The adequate characterization of citrus varieties is of great importance for their distinction from those already known, and is essential for their registration in the Brazilian RNC of MAPA. New materials need to be characterized and evaluated under different soil and climatic conditions before they can be made available as scion or rootstock.

Researchers collect and analyze data on the plant growth and production, fruit and juice quality, scion/ rootstock compatibility, and tolerance to pests and diseases of new materials (ZORZO; CARVALHO, 2012). Based on research and consolidated records, most of the citrus varieties used in São Paulo and other Brazilian states have the desirable vegetative and fruit aspects that are well-described in the literature (FIGUEIREDO, 1991; KOLLER, 1994; DONADIO et al., 1995; POMPEU JR., 2005; PIO et al., 2005). In nursery is recommended that lots of seeds and budwoods used for propagation must checked for their respective morphological description, as early mentioned, aiming to ensure varietal fidelity. This procedure maximize the use of propagules free of variations caused by mutations that may compromise the quality and productivity of the clones (PERIN, et al., 1998).

More detailed genetic characterization for the purpose of cultivar protection can be done using morphological descriptors. These parameters can be found in the manual 'Descriptors for Citrus' of the International Plant Genetic Resources Institute (IBPGR, 1988), and in the guidelines for the examination of homogeneity and stability distinction established by the 'International Union for the Protection of New Varieties of Plants' (UPOV, 2003).

On the other hand, similar rootstock genotypes are difficult to differentiate, especially in the early stages of growth, when their morphological and agronomic characteristics are not fully expressed. Biotechnological tools, including isoenzymatic and molecular markers, have been used to identify seedlings of zygotic origin in breeding programs and in citrus nurseries (ASHARI et al., 1988; ANDERSON et al., 1991; CRISTOFANI; MACHADO, 1998; ANDRADE-RODRIGUEZ et al., 2004; ANDRADE et al., 2007). Molecular markers are also useful for the genetic certification of citrus varieties used as scions (NOVELLI et al., 2004, 2006; MORAES FILHO et al., 2011; SUN et al., 2012; SANKAR et al., 2014) and as rootstocks (SHÄFER et al., 2004; SCHINOR et al., 2011). As an example, the use of microsatellite or simple sequence repeats molecular markers allowed 'IAC 2019Maria' to be genetically differentiated from 'Murcott IAC' tangor, which is used as a female parent in crosses with 'Pera IAC' sweet orange (CRISTOFANIYALI, 2017).

For sweet oranges, promising results have also been obtained with the use of the laser-induced fluorescence spectroscopy (LIFS) technique, which uses the optical properties of leaves to distinguish varieties based on their chemical composition and to differentiate between healthy and diseased citrus plants (MILORI et al., 2013). The use of LIFS made it possible to discriminate varieties, or even sweet orange clones, with a specificity of $97.5 \%$ (KUBOTA et al., 2017). This technology is a potential tool for the early identification of seedlings in breeding programs, characterization of accessions in germplasm banks, and certification and protection of cultivars. The LIFS technique presented better results in the differentiation of 'Sunki' mandarin selections than the use of molecular markers, which only differentiated 'Sunki Tropical' and 'Sunki Maravilha' from one another and their parents, but did not differentiate the common 'Sunki' and 'Sunki da Florida' varieties from one another (SANTANA-VIEIRA et al., 2014).

Aiming to meet the demands of the Brazilian citrus industry, the CCSM-IAC, in Cordeirópolis, SP, has been providing genetic certification for rootstock varieties since the early 2000s (COLETTA-FILHO et al., 2004). Analyses are conducted using the DNA polymerase chain reaction technique and have been used to identify rootstock citrus varieties at the sowing stage, whereas the differentiation of varieties at this stage based on morphological characteristics, such as leaf and thorn morphology, is uncertain. The same applies at the seed stage. Characteristics such as seed size and shape are very useful if the genotypes are different but can lead to uncertainty (Figure 1). Exampling the phenotypic differentiation between trifoliate hybrids, such as citranges and citrumelos (Figure 1) and the 'Cleopatra' and 'Sunki' mandarins (Figure 2), in the initial phase of growth is still very uncertain. The genetic confirmation of the rootstock of an adult plant in the field is also possible, but for this purpose it is necessary to obtain a piece of a root or bark below the grafting region. 
A
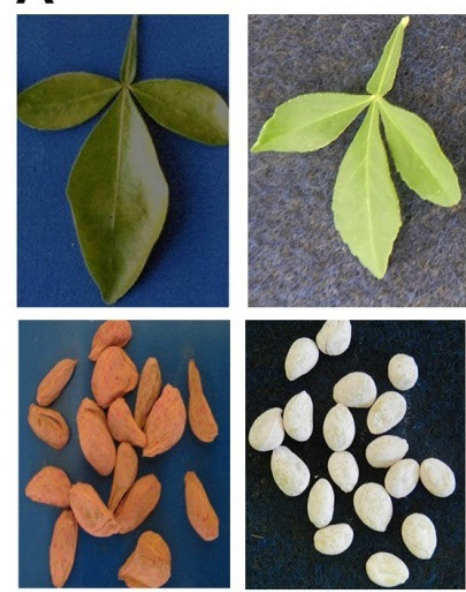

Citrange - CT Trifoliata - TR

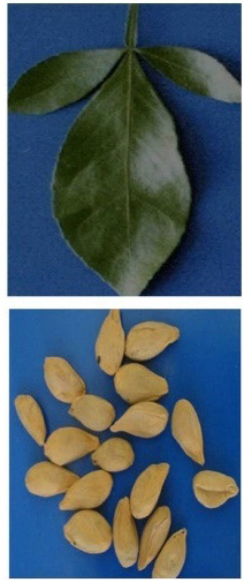

Swingle - SW Citrandarin - Cl

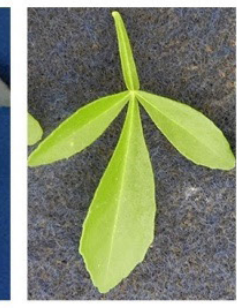

B

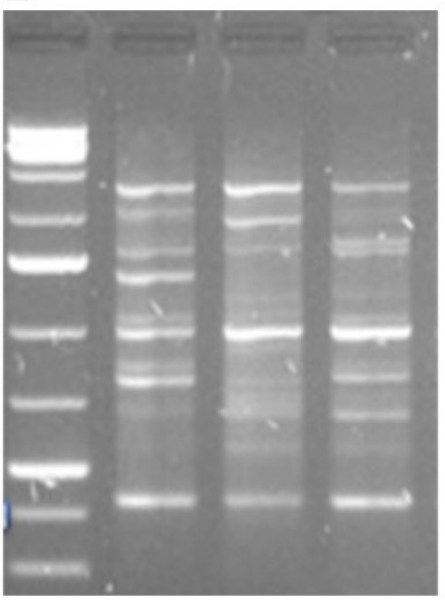

CT TR SW

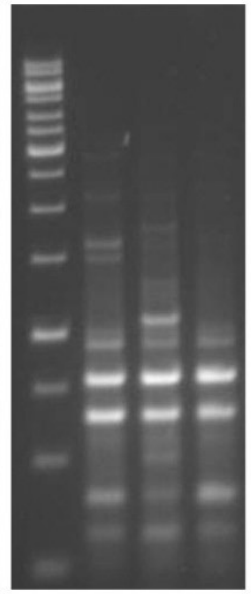

Differents $\mathrm{Cl}$

Figure 1. Differences in seed and leaf morphology, as well as electrophoretic profile for rootstocks with trifoliate leaves: citrange (CT), Poncirus trifoliata (TR), 'Swingle' citrumelo (WS) and Citrandarin (CI). A) Similarity in leaf morphology and variation in seed morphology of different materials. B) Electrophoretic profile of the PCR using random primers - RAPD. Different selections of citrandarins. Photos: Helvécio Della Coletta Filho

A

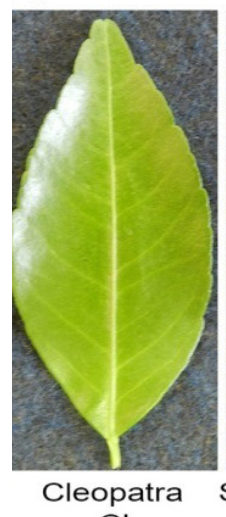

$\mathrm{CL}$

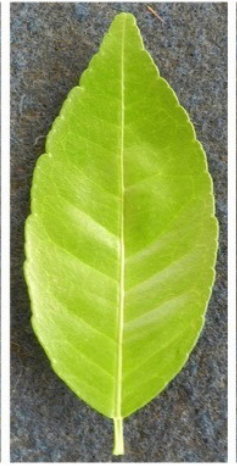

Sunki Maravilha Sunki Tropical SM

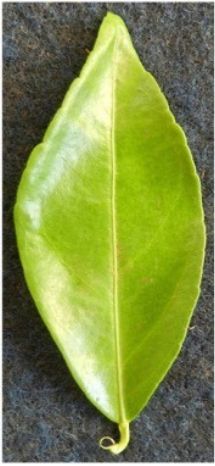

$\mathrm{STr}$

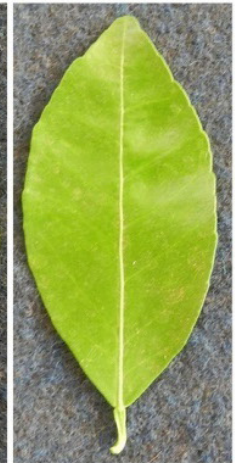

Sunki Tiête ST

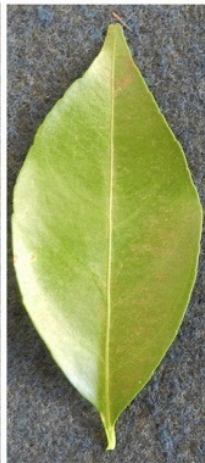

Sunki SK
B

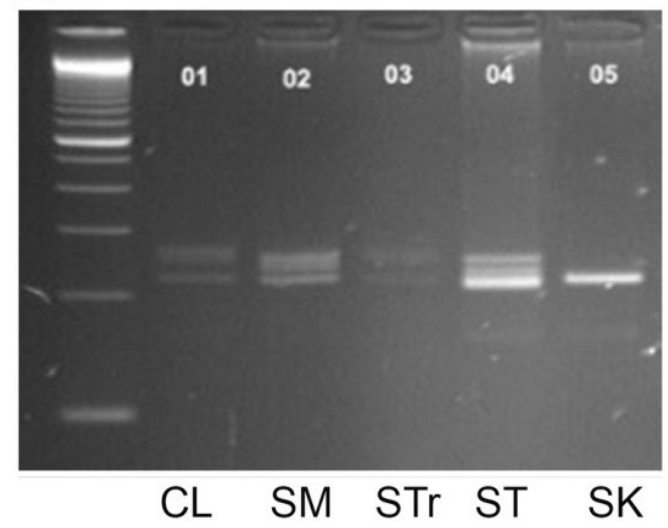

Figure 2. Morphological and molecular comparisons of the main varieties of mandarins used as rootstocks. A) Leaves of the mandarins Cleopatra (CL), 'Sunki Maravilha' (SM), 'Sunki Tropical' (STr), 'Sunki Tietê' (ST), and commom 'Sunki' (SK). B) Electrophoretic profile of PCR obtained with microsatellite primers - SSR. Photos: Helvécio Della Coletta Filho.

The studies conducted by the CCSM-IAC in recent years using molecular markers for the genetic differentiation of citrus varieties allowed a specific set of primers to be selected that can differentiate among the main varieties and species used as rootstocks (COLETTA-FILHO et al., 1998; CRISTOFANI-YALY et al., 2003; 2011) (Table 3). This test is conducted by comparing the suspect material against reference standards belonging to the CCSM-IAC germplasm bank. Several rootstock varieties, such as trifoliates and their hybrids (with trifoliate leaves), lemons, and mandarins can be molecularly certified using these selected primers (COLETTA-FILHO et al., 2004). 
Table 3. Primers selected in research studies (COLETTA-FILHO et al., 1998; CRISTOFANI-YALY et al., 2003; 2011) and currently used in the genetic certification processes at the Campinas Agronomic Institute's Sylvio Moreira Citrus Research Center.

\begin{tabular}{llll}
\hline Primers & Sequence & Category & Group of differentiated rootstocks \\
\hline OPR04 & CCCGTAGCAC & Random & Rangpur lime and Volkamer lemon \\
\hdashline OP AB18 & CTGGCGTGTC & Random & P. trifoliata and hybrids \\
\hdashline OP M04 & GGCGGTTGTC & Random & P.trifoliata and hybrids \\
\hdashline OP M15 & GACCTACCAC & Random & P. trifoliate and hybrids \\
\hdashline CCSM 6R & CCTCTATTAATGTGCCTG & Microsatellite & Mandarins \\
CCSM 6F & TCTGTGTGAGGACTGAA & & \\
\hline
\end{tabular}

In the trifoliate group, genetic certification can be successfully done for several selections of $P$. trifoliata, such as 'Limeira', 'Davis A', 'Argentina', and 'Rubidoux'. The citrumelo selections 'Swingle', 'F80-5', 'F80-8', and 'F80-18' (all intergeneric hybrids of $P$. trifoliata $\times$ $C$. paradisi), as well as citranges (intergeneric hybrids of $P$. trifoliata $\times C$. sinensis), can be genetically certified with a high degree of confidence. However, the 'Troyer' and 'Carrizo' citranges, which seem to be different denominations of the same germplasm, are exceptions to this (SAVAGE; GARDNER, 1965). Selections of citrandarins may also be genetically discriminated from their trifoliate parent, and from other selections that have the trifoliate leaf as the dominant marker (Figure 1).

Information on lemons and their relatives are only available for the 'Rangpur' lime and 'Volkamer' lemon, since only a few genetic materials are available. The genetic certification in this group of rootstocks is made mainly using lots of seeds, seedlings, and pieces of the rootstock trunk bark already planted in orchards. However, it is not possible to genetically separate the selections 'Palermo', 'Catania 1', and 'Catania 2' from the 'Volkamer' lemon. Selections of 'Rangpur' lime with horticultural differences reported by Pompeu Jr. (2005) were insufficiently separated by the available molecular markers, indicating the need to search for other molecular tools.

Among mandarins, genetic certification is required at the seedbed phase, at which 'Sunki' and 'Cleopatra' are morphologically similar (COLETTA-FILHO et al., 2004). According to these authors, microsatellite-based primers (CCSM 6R/6F) allowed the 'Sunki' mandarin nucellar clone to be separated from other selections such as 'Tietê', 'Tropical', and 'Maravilha' (Figure 2).

\section{Production of propagation material}

Regulations for the production of propagation material: Standardization and frequent nursery inspections are of great importance to organizing a system for the assurance of the genetic and sanitary quality of citrus nursery tree production and propagation materials. These objectives are achieved through the establishment of registration and certification programs for mother trees, such as those applied in other countries like Spain (PINA et al., 2015) and the USA (VIDALAKIS et al., 2010).

In Brazil, the Citrus Mother Tree Program of the State of São Paulo was established in 1969 (GREVE et al., 1991), and restructured in 1998 to require the use of screens in all nurseries to protect the plants against CVC vectors (CARVALHO, 1998). The mandatory use of screens was also the main restriction of the Standards for Production of Certified Nursery Trees, a São Paulo state voluntary program introduced in 1994 (NORMAS, 1998). The use of screens was also adopted in January 2003 as a mandatory rule in the production of nursery trees in this state (CARVALHO, 2004).

The São Paulo State Citrus Mother Tree and the Certified Nursery Trees programs were aimed at the development and dissemination of technology for the production and release of healthy citrus basic materials and were supported by research institutes and public policies (CARVALHO; LARANJEIRA, 1994; BORGES et al., 2000; CARVALHO et al., 2001a; VALLE, 2002). These programs were the basis for the implementation and improvement of standards and techniques for the production of nursery trees and basic materials in protected environments to exclude the vectors of important diseases, such as CVC and HLB, which made the system used in this state a reference system to be used as a model worldwide.

On a historical note, the legal agreement between the São Paulo State's Secretary of Agriculture and Food Supply (SAA-SP) and MAPA lost validity with the new nationwide law of Seed and Nursery Trees of July 2004 (DECRETO, 2017), causing a major setback to the citrus industry. The Standards for Citrus Nursery Tree Production and the Certified Nursery Tree Production System were also extinguished on this occasion (CARVALHO, 2014). Today, the São Paulo State Agricultural Defense Coordination, linked to the SAA-SP, acts only within the phytosanitary aspects of its legal competence, focusing on the physical and genetic standards indicated by MAPA.

According to the federal regulations of December 2005 (INSTRUÇÃO, 2017b), all agents involved in the execution of production activities must register or be certified in the National Nursery Trees and Seed 
Registry (RENASEM) of MAPA. There are specific conditions and documentation for this registration, including the obligatory use of the species or cultivars included in the RNC of MAPA, proof of genetic origin, technical responsibility for the respective class entity, and certificates of genetic sanity.

Nationwide, the production of citrus nursery trees on substrate containing soil has not been allowed since September 2017 (INSTRUÇÃO, 2017a). The mother trees, certified budwood blocks, and certified nursery trees should all be kept in a protected environment, covered by screens with maximum mesh size of $0.87 \times 0.3 \mathrm{~mm}$, with an antechamber of at least $4 \mathrm{~m}^{2}$ and a footbath at the entrance (INSTRUÇÃO, 2017d). In areas with frequent occurrences of HLB, the certified budwood increase blocks and nurseries must also be kept under a screen, even if they are not used for the production of certified budwood or certified nursery trees (INSTRUÇÃO, 2017e). The regulation of the production of citrus rootstocks by in vitro micropropagation is also encompassed by federal regulations, which establish the standards for the production and commercialization of nursery trees and other propagation structures obtained through tissue culture (INSTRUÇÃO, 2017a).

In addition to the federal regulations of MAPA, all those involved in the production and commercialization of citrus propagation materials in the state of São Paulo must also comply with state regulations, such as the mandatory use of screens to protect the nursery trees and mother trees against CVC and HLB vectors, with the exception of rootstock mother trees (SÃO PAULO, 2018b). This is also mandatory for citrus budwood increase blocks and nurseries (SÃO PAULO, 2018c), and citrus nursery tree storage areas (SÃO PAULO, 2018a). The methodology for collecting samples for laboratory analyses of plant health in basic plants, mother trees, seed supply plants, budwood increase blocks, nurseries, and citrus nursery tree storage areas is also standardized (SÃO PAULO, 2018d).

Mother trees: The trees that supply seeds and budwood are commonly called mother trees and are obtained through the selection of plants from commercial orchards or breeding programs. Their introduction from other countries is strictly regulated by Embrapa Genetics Resources and Biotechnology (EMBRAPA, 2016) or IAC (QUARANTENÁRIO, 2016), and should follow all quarantine rules to avoid the introduction of new pests and diseases, such as the viruses described in Table 4, whose occurrence has not yet been reported in Brazil.
Plants that are candidates for mother trees should be tested for the presence of systemic pathogens, which may compromise the production or longevity of the plants originating from them. In Brazilian conditions, in addition to severe strains of CTV, the plant health is evaluated for the occurrence of exocortis, psorosis, cachexia, decline, CVC, and HLB (CARVALHO et al., 2005). The plants supplying propagation materials must also be free of the citrus canker and of the citrus leprosis virus, although these diseases are not systemic and present lesions limited to the affected organs (branches, leaves, and fruits).

Increasingly faster and more accurate immunological and molecular tests are becoming available, but the diagnosis of the presence of certain pathogens is still dependent on the application of biological tests using indicator plants (Table 4). For the establishment of a complete mother tree program, other steps are also necessary, such as shoot tip-grafting, either associated (or not) with thermotherapy and cross-protection against the most severe isolates of CTV or pre-immunization (MÜLLER; REZENDE, 2004). Only plants maintained in a vector-free, protected environment are used in these processes.

These programs require equipment, products, and specialized technical personnel. The high cost and time required to perform this work restricts it to being done at more complex research institutions, larger companies, or nurseries. These services may be requested from such institutions as the CCSM-IAC (INFORMATIVO, 2017), and all selected materials must be registered by qualified technicians registered in the RNC and RENASEM of MAPA.

Shoot-tip grafted plants provide buds for the establishment of citrus mother trees, since they are pathogen-free and pre-immunized against severe strains of CTV (Figure 3A-C). The use of an anti-aphid screen and antechambers are federal requirements and prevent the entry of insect vectors of diseases. The structure used must be resistant to strong winds and must have a minimum height of $4 \mathrm{~m}$ to ensure good internal ventilation (CARVALHO; SETIN, 2014). The use of windbreaks is recommended to protect the structure against inclement weather, and as a preventive practice against contamination with the citrus canker bacteria (BEHLAU; BELASQUE JR., 2014). 


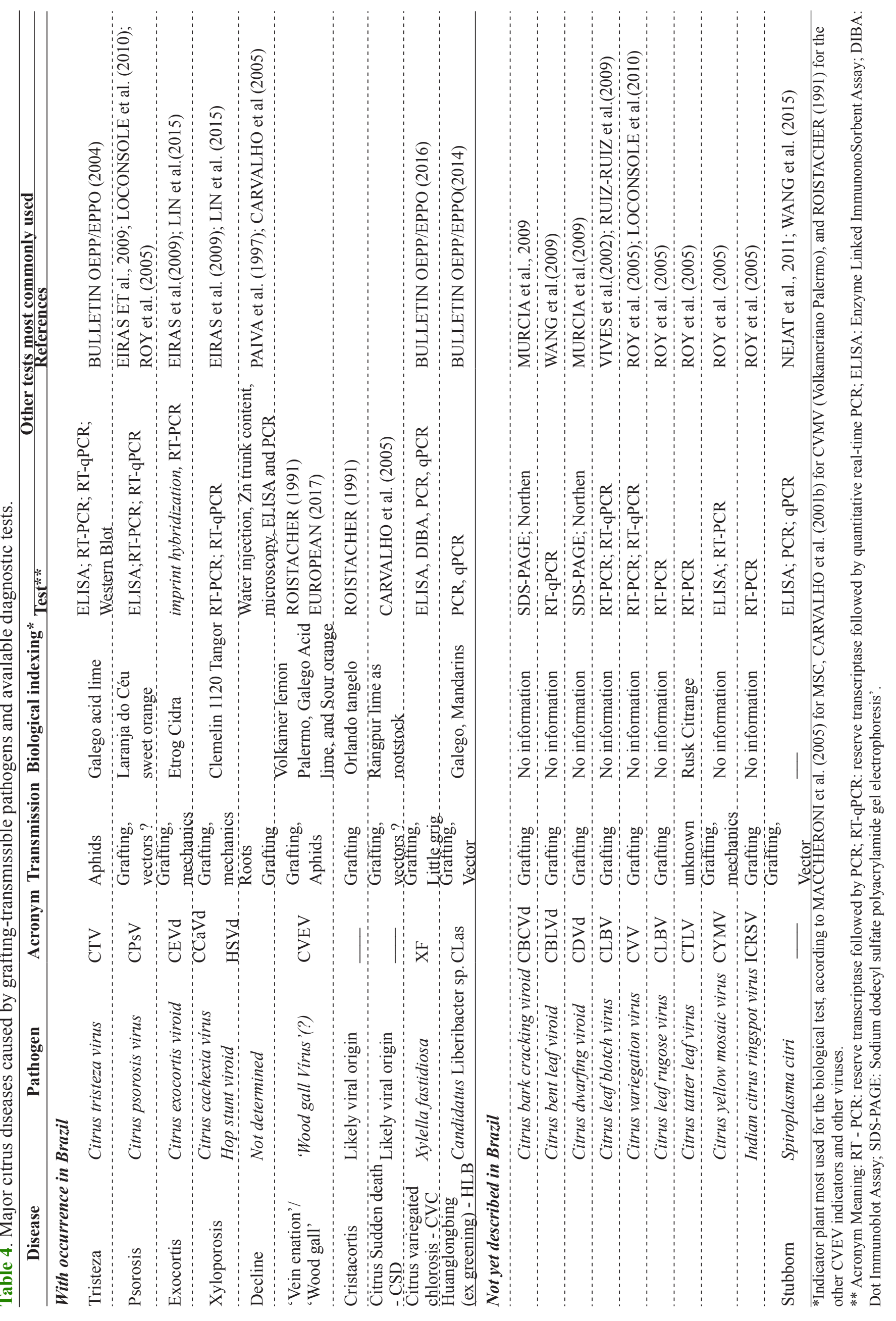


In addition to citrus canker, specific management practices should also be adopted to avoid contamination with CVC, HLB, and other diseases. Spraying with registered chemical or biological pesticides should be performed when symptoms of scab (caused by the fungus Elsinoë fawcettii Bitancourt \& Jenkins) or citrus black spot disease [caused by the fungi Guignardia citricarpa Kiely (teleomorph) and Phyllosticta citricarpa (McAlp.) van der Aa (anamorph)], or the presence of aphids, mites, cochineal scales, or the citrus leaf miner, is detected inside the screened environments. The use of adhesive insect traps is also required. Strict control is necessary of door opening and personnel entrance, and the disinfestation of footwear, vehicles, equipment, and tools is highly recommended (CARVALHO et al., 2005). The São Paulo state ordinances do not regulate the quality of water used in the irrigation of mother trees; however, they recommend that attention be paid to not to let water from flooding or insects from the ambient environment enter through drainage holes.

For mother trees planted on the ground (Figure 3C), the same cultural practices used in commercial orchards, such as soil and leaf analyses, liming, and fertilization via soil, fertigation and/or foliar application, is recommended. In addition to routine inspections, samples of plants suspected of having citrus canker or other diseases should be taken for laboratory tests. Mother trees grown in pots or soil should be evaluated annually, and the samples should be sent to a certified laboratory for testing for CVC and HLB (CARVALHO et al., 2005). The occurrence of viruses and viroids in ornamental citrus mother trees was reported by Rizzo et al. (2017) in Italy. The possibility of contamination with diseases transmitted by insect vectors from other plants and commercial orchards emphasizes the importance of the health care of citrus plants produced for all uses, not just in the production of nursery trees for use in industrial juice processing and the fresh fruit market.

As there is no evidence of pathogen transmission through seeds, the mother trees of rootstock varieties may be kept in open-air conditions, but they must also be periodically indexed for viruses, blight, CVC, and HLB (CARVALHO; SETIN, 2014).

Budwood increase blocks: These blocks consist of high-density groups of plants kept in pots or directly in the ground and are exclusively intended for the production of budstick branches. To produce citrus certified budwood, these plants must be maintained in completely enclosed and screened houses, under a screen with an antechamber in the entrance according to federal regulations.

The height of the screened housing influences the internal temperature of the budwood increase blocks, especially when using very large production facilities and a plastic ground cover, which is mandatory in the state of São Paulo. The use of drip irrigation and the plastic ground cover reduces and/or eliminates the leaching of products used to control pests and diseases and the excessive accumulation of water in the trunk, branches, and leaves, reducing susceptibility to such diseases as Phytophthora gummosis and citrus canker (BEHLAU; BELASQUE JR., 2014). The use of plastic in the roof and side walls also allows the use of heat in the colder months of the year.

The plant spacing used in these screened houses depends on the cultivation system adopted by the nurserymen. For the production of budsticks with two or three branches, spacing between 0.3 and $0.4 \mathrm{~m}$ has been used within a system of single or double rows spaced from 0.7 to $1.0 \mathrm{~m}$, obtaining up to 200 buds per plant per year when the plants reached maximum production (CARVALHO, 1998; CARVALHO et al., 2000a).

For the formation of budwood increase blocks, a vigorous rootstock with a satisfactory tolerance to Phytophthora gummosis, such as the 'Rangpur' lime, should be used. This rootstock is considered to be of moderate susceptibility to this disease according to Pompeu Jr. (2005). The accumulation of moisture and lack of ventilation caused by high densities of plants may favor the development of this and other diseases (CARVALHO et al., 2005). As an option that can be planted directly on the ground, the trees multiplied with budwood increase blocks can be maintained in containers with variable substrate capacities of 4 to $20 \mathrm{~L}$ (Figure $3 \mathrm{D}-\mathrm{F}$ ). The maximum legal period of use of an increase block is 5 years (SÃO PAULO, 2005b). This system allows for the easier substitution of plants but requires greater care with the use of fertilizer and better irrigation management. The substrates used should be free of pathogens, lightweight, and have good drainage. The most common mixtures used are based on pine bark and coconut fiber.

To monitor for different species of sharpshooter leafhoppers (Homoptera: Cicadellidae) and psyllids (ACP, Diaphorina citri Kuwayama) in the budwood increase blocks, yellow adhesive sticky traps should be placed in the screened house to monitor its insect population (HALL, 2009). The use of these traps is also efficient to monitor for ACP inside screened houses used for the production of HLB-free citrus nursey trees under protective systems (FERRAREZI et al., 2017b). The application of fungicides, insecticides, and acaricides recommended for citrus crops should also be performed with products in rotation using different modes of action and active ingredients (CARVALHO et al., 2005).

Irrigation and fertigation in budwood increase blocks: The irrigation of budwood increase blocks in pots should be performed to supply the tree's water demand based on monitoring the substrate moisture. This can be estimated by manually sensing the substrate (empirical and inaccurate method) and by monitoring the weight of the containers (SPANN; FERGUSON, 2014) or, more precisely, by soil moisture sensors [time-domain reflectometry (TDR), frequency-domain reflectometry (FDR), and others]. In addition, it is possible to monitor the weather conditions to calculate the evapotranspiration rate, allowing for greater precision in irrigation management. 
Methods based on measuring the sap flow in citrus budwood using micro-sensors inserted in a section of the stem have also been studied (GIRARDI et al., 2010a). Although the daily water consumption can be measured directly using low-cost sensors that can be manufactured by the nurseryman, the latter method is still experimental and can cause physical damage to the stock trees after prolonged use.

The most common irrigation methods used for budwood increase blocks are the drip irrigation system and manual irrigation using hose nozzles, rain wands, and overhead micro-sprinklers. Most nurserymen also use a rigid schedule based on timers to control irrigation. The use of automatic timers can be problematic since they do not take into consideration water demand and water availability based on the environmental conditions and plant growth stage.

Regarding the fertilization of budwood increase blocks, an adequate balance of nutrients is necessary to avoid deficiencies. Granular, controlled-release, and water-soluble fertilizers used for fertigation (supplied using separate tanks of pre-prepared blends or complete solutions) can be used, but at faster rates. It is recommended that adequate concentrations of $\mathrm{N}$, $\mathrm{P}, \mathrm{Mg}$, and micronutrients are maintained to stimulate the growth of sprouts that will produce the buds to be used for grafting. Bataglia et al. (2008) recommend a balanced formulation for nursery trees in bags that should be adjusted for the budwood increase blocks. Further research is needed to recommend fertilizer types, sources, and application rates, as well as updated guidelines for different varieties and rootstocks.

Collection and processing of buds: The budsticks can be harvested as soon as the branches became semiwoody, with dark-green mature tissue and triangular edges. The branches are cut with disinfected pruning clippers used only for this task and transferred to a clean and shaded place to remove the leaves. The extremities of the budsticks are removed, leaving the central part with approximately 10 to 15 buds (CARVALHO et al., 2005).

The budsticks can be stored at $8^{\circ} \mathrm{C}$ if not used immediately (ROMEIRO et al., 2001). The sticks are pre-treated with fungicide and placed on a clean and ventilated rack to dry in the shade. If the citrus blackspot (Guignardia citricarpa Kiely) disease's causal agent is present in the producing region, the budsticks can be transported without risk to other disease-free regions, according to the São Paulo state regulation for the transit of propagation material. A heat treatment to inactivate the fungus is recommended by immersion in heated water at a temperature of $50^{\circ} \mathrm{C}$ for $15 \mathrm{~min}$ (CARVALHO et al., 2005). Due to the important damages caused by them to citrus trees, attention should be paid to the presence of the phytophagous mite vectors of the disease, such as the citrus rust mite, citrus bud mite, and especially the citrus leprosis mite. According to Carvalho et al. (1989), the use of Binapacril at $0.2 \%$ presented $100 \%$ efficiency in controlling these citrus mites without compromising the quality of the bud eyes for use in grafting.

\section{Nursery tree production}

The nurseries used for the production of citrus trees are completely enclosed, with an antechamber and a footbath with cupric and bactericidal products at the entrance for disinfection (BREMER NETO, et al., 2015). The same applies for the production of propagation materials, such as mother trees and budwood increase blocks. The plastic roof facilitates sanitary and irrigation management and allows the use of heat to increase plant growth during winter. The use of $50 \%$ shading screens, reflective screens, or other roof coatings can reduce the effect of high temperature and is widely used during the germination phase (CARVALHO; SETIN, 2014). During the night, the interruption of the dark period for one hour with the use of artificial lighting results in greater growth of sweet orange trees grafted on rootstocks sensitive to short photoperiods, such as 'Carrizo' citrange and 'Swingle' citrumelo (BRAR; SPANN, 2014).

In February 2017 the state of São Paulo adopted the status of an Area under Risk Mitigation to follow the changes in federal regulations related to the establishment and maintenance of the phytosanitary status of citrus canker disease (INSTRUÇÃO, 2017c). The actions needed to eradicate or suppress citrus canker are no longer required there; rather, only measures to prevent the disease spreading to other areas and its management are required (RESOLUÇÃO, 2017). The citrus tree nurseries should be located $200 \mathrm{~m}$ away from any disease focus. In the case of the disease's occurrence, a 1000-m quarantine zone is required for protection against the disease and to avoid nursery interdiction in the event of canker occurrence in adjacent areas (PORTARIA, 2017).

The citrus tree production system can be divided into multiple, successive phases based on the nursery operation as follows: seed production and extraction, seed coat removal, germination in seedbeds, liner production, rootstock transplanting, grafting, and termination. Each of these phases is performed in specific facilities and follows strict state and federal regulations to guarantee tree health and quality. The specific details of each phase are discussed in the following sections.

Seed production, collection, processing, and storage: The rootstock seeds must be obtained from fully matured fruit, characterized by the typical peel color of each species. Seeds obtained from immature fruit may present germination problems, especially for $P$. trifoliata and hybrids. The use of fruit harvested from the ground and near the tree skirt is not recommended to avoid the occurrence of fungal diseases that may cause problems with seed conservation and seedlings damping-off. For the same reason, manual or mechanical seed injury during extraction must be avoided. The complete removal of the seed mucilage by immersion of the seeds in hydrated 
lime solution and subsequent washing must be carried out, followed by a heat treatment at $52^{\circ} \mathrm{C}$ for 10 minutes (CARVALHO et al., 2005).

Citrus seeds are recalcitrant, presenting challenges in the maintenance of their physiological quality when kept in storage at low moisture content when compared to other types of seeds (CARVALHO et al., 2002). In addition to treatment with fungicides, citrus seeds should be stored at low temperatures and properly wrapped in well-sealed plastic bags. Despite the gradual loss of germination potential with storage time, the seeds can be maintained in storage for up to 1 year (SIQUEIRA et al., 2002;
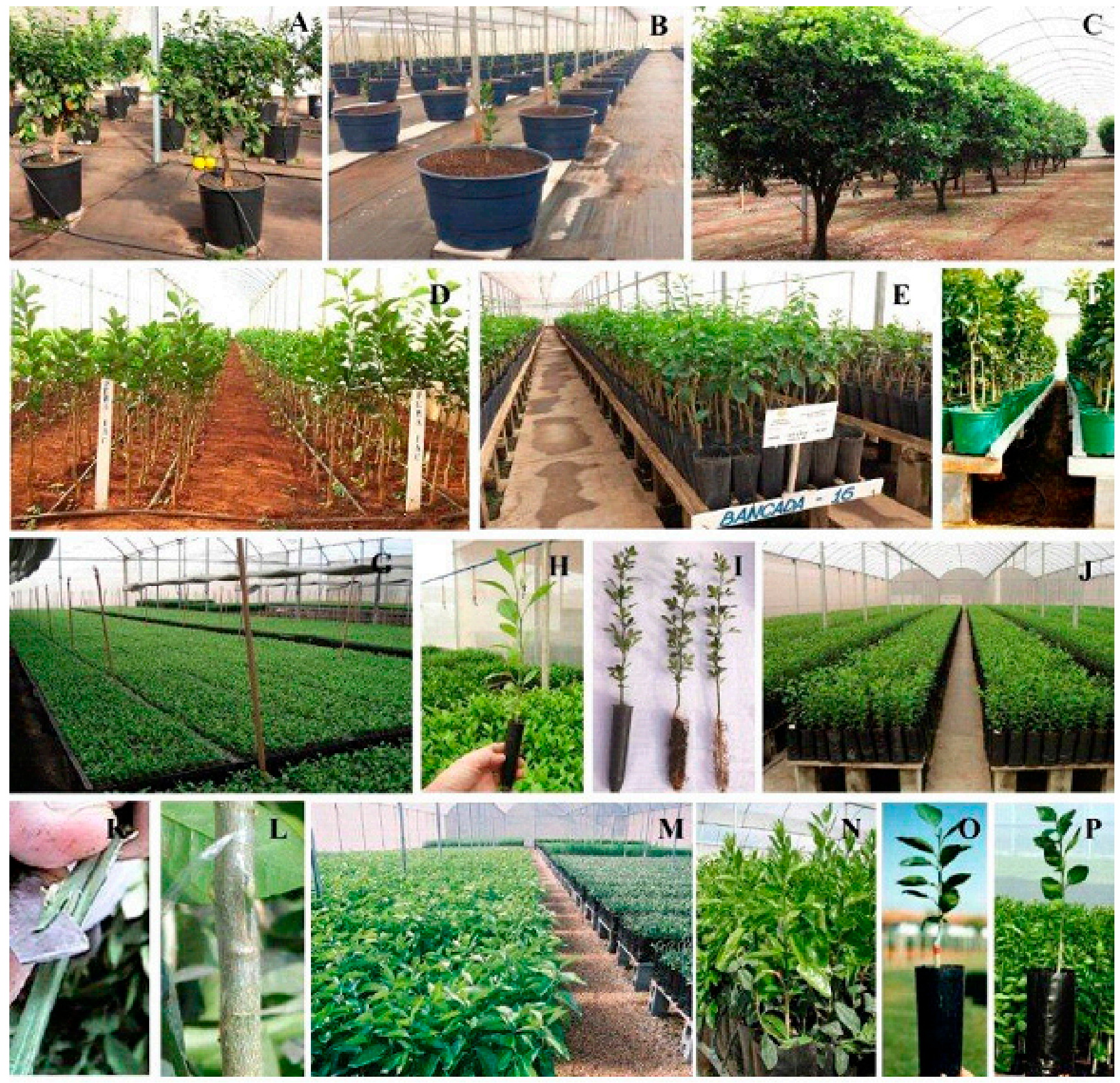

Figure 3. Irrigation systems used in commercial citrus nurseries for the production of rootstock seedlings, nursery trees and budstick in budwood increase blocks: A) shower head, hose nozzle or rain wand (Photo: Rhuanito Soranz Ferrarezi); B) perforated PVC pipes (Photo: Conan Ayade Salvador); C) micro sprinklers; D) spray bars; E) drip system; F) ebb-and-flow subirrigation (Photos: Rhuanito Soranz Ferrarezi) and G) Mobile bar in budwood block (Photo: Sérgio Alves de Carvalho). 
CARVALHO; SILVA, 2013; CONCEIÇÃO et al., 2015).

Seedbed: The container type used in this phase is a cone-shaped plastic tube of $0.05 \mathrm{dm}^{3}$ volume, with longitudinal furrows that induce root growth toward the basal orifice, causing root meristem pruning. This 'air pruning' of the pivotal root favors the emission of secondary roots and increases root system development in comparison to seedlings grown in soil or other pot shapes (CARVALHO et al., 2005). The containers should be kept suspended using plastic trays hanging over cables fixed to wooden or concrete posts (Figure $3 \mathrm{G}-\mathrm{I}$ ). The use of these containers facilitates plant sorting into homogeneous lots and optimizes tree management. Regarding the substrates, commercial products with a base of pine bark, vermiculite, organic materials, and/or coconut fiber have been used extensively. The potting mix should have a finer grain size than those used in the bags due to the small volume of the container. Growth media also must be pathogen-free, lightweight, of adequate porosity with good drainage, physically and chemically stable, and should not contain nutrients like boron (B) in excess to avoid toxicity (MATTOS JR. et al., 1995; PERIN et al., 1999).

The removal of the seed tegument can be done manually after treatment with abrasive or caustic products. This procedure favors the speed and uniformity of germination and was well-described by Bremer Neto et al. (2015). The effectiveness of seed coat removal may vary according to the rootstock variety used and should only be done at the time of sowing (GIRARDI et al., 2007a; TEIXEIRA et al., 2009; CARVALHO; SETIN, 2014). While seeding, only two or three seeds should be used per container, and one should avoid placing the seed with the micropyle in the upward position to reduce root deformation caused by kinking or curling (SILVA; CARVALHO, 2007).

Seedling sorting after germination is an important process to eliminate atypical plants, which are often of hybrid or zygotic origin and have different leaf patterns and abnormal development. The occurrence of these variations depends on the rootstock, with higher percent occurrences in materials with lower rates of polyembryony, such as 'Rangpur' lime, in which the seedling discard rate can reach up to $60 \%$ (BREMER NETO et al., 2015).

Transplanting: The seedlings reach 10 to $15 \mathrm{~cm}$ in height between 3 to 5 months after sowing, depending on the variety and the growing conditions. The liners containing the seedlings' root masses can be transplanted into larger containers to complete rootstock growth. The transplanting provides uninterrupted growth of the rootstock due to the reduction of root ball formation. The transplanted rootstock can be grafted within 3 to 4 months (CARVALHO et al., 2005).

The process of citrus rootstock production by micropropagation starts in the laboratory, using growth rooms and appropriate combinations of growth regulators and nutrients for multiplication, elongation, and rooting. Information is available in the literature for different species (CARVALHO et al., 1991; SEN; DHAWAN, 2010; EED et al., 2011). The various aspects of this methodology are also discussed by Carimi and De Pasquale (2003), including seedling acclimatization under screened conditions and when grown in containers, following the same procedures as recommended for seed germination above.

Nursery phase: The containers for this growing stage should be at least $10 \mathrm{~cm}$ wide and $30 \mathrm{~cm}$ tall, with a substrate capacity of $4 \mathrm{~L}$. Containers with higher capacity allow for greater vegetative growth (GIRARDI et al., 2005 b), although recent studies indicate that there is potential for the production of grafted trees in containers with reduced capacity $(180 \mathrm{~mL})$ (GIRARDI et al., 2017). The most common materials used are plastic bags, which are foldable, present lower costs than rigid containers, and have the advantage of being a recyclable material, with no need for returning, washing, and disinfestation for later use. The bags are arranged in groups of $4,6,8$, or 10 lines per bench, depending on the diameter, and should be suspended from the ground, hanging from benches with a minimum height of $40 \mathrm{~cm}$ and made of cement blocks and pre-fabricated material, but not wood (Figure 3J). A regular nursery can produce on average 20 to 25 trees per square meter, depending on the number and size of circulation areas, container size, and number of tree lines used per bench (CARVALHO et al., 2005).

Regarding the substrate used, the media granulometry recommended for the final phase of the production process is one with a higher proportion of particles between 0.5 and $4 \mathrm{~mm}$ in diameter, which is larger than the substrates used for the seedbed phase (ZANETTI et al., 2003). There are several commercial blends of the appropriate substrate currently available on the market (MOURÃO FILHO et al., 1998; ZANETTI et al., 2003; SETIN et al., 2005; FOCHESATO et al., 2007).

Grafting and conduction: Grafting is usually performed at 10 to $20 \mathrm{~cm}$ from the substrate surface by normal T- or inverted T-type budding (INSTRUÇÃO, 2017d). For the production of inter-grafted trees, the bud of the scion variety should be placed $10-12 \mathrm{~cm}$ above the grafting point of the inter-grafted variety (BREMER NETO et al., 2015). The bud union is covered by plastic tape (traditional or degradable), which may or may not require removal depending upon the type used. After grafting, the rootstock stem is bent to induce sprouting. This technique presents increased vigor compared to that involving the decapitation of the rootstock above the grafting point (CARVALHO; MACHADO, 1997; PEREIRA; CARVALHO, 2006).

The lateral sprouts should be removed over time, and the sprouting of the grafted bud is conducted in a single stem system until maturation. The conduction can be done with or without tutors (metallic, plastic, or wooden stakes). The final pruning is performed when the stem is 
between 40 and $50 \mathrm{~cm}$ in height, and the cut area should be treated with fungicides. The tree can be planted as a single stem or kept in the nursery for canopy sprouting, with three to five spiral branches. To avoid the formation of a root ball, the tree should be maintained in the nursery for a maximum of 15 months from the rootstock sowing when it has a single stem, and for up to 24 months for nursery trees with branches (CARVALHO et al., 2005).

Irrigation of rootstock liners in the seedbed: The irrigation systems traditionally used in the production of citrus liners include manual watering using shower heads, hose nozzles, rain wands, and perforated PVC pipes (Figures 4A and 4B) (SALVADOR et al., 2016), micro-sprinklers (Figure 4C), and spray bars (Figure 4D) (TESTEZLAF; FERRAREZI, 2017).

Although widely used in seedbeds and nurseries, manual overhead irrigation using shower heads, hose nozzles, rain wands (Figure 4A), or perforated pipes (Figure 3B) requires intensive labor, and presents low application efficiency and excessive leaching, with the potential for soil, groundwater, and water table contamination with agrochemicals. On a seedbed, the use of overhead irrigation causes total canopy wetting, which favors the dissemination of certain diseases, such as citrus canker (BELHLAU; BELASQUE JR., 2014).

The irrigation of a seedbed can be automated with the use of spray bars designed to apply water through nebulizer sprays mounted on metal structures that automatically move on rails along the length of the greenhouse (Figure 4D). The amount of water applied is controlled by adjusting the speed of the moving spray structure. To eliminate the potential damages caused by the size of the droplets, nebulizer sprays should produce small droplets, but with enough flow to cross the leaf canopy and reach the substrate surface (TESTEZLAF; FERRAREZI, 2017).

New, innovative irrigation methods are needed to increase irrigation efficiency and eliminate the drawbacks of overhead irrigation. Subirrigation, an irrigation method that applies water to the bottom of containers and allows for its recirculation, is already available and is commercially used in other large plant production industries, such as those producing ornamental and woody species. This system induces the vertical movement of water through the substrate by the capillary rise principle. For comparative purposes, the data available in the literature indicate that sprinkler irrigation has an irrigation efficiency of $9 \%$, the drip and capillary mats of $53 \%$, and the subirrigation benches of $77 \%$ in the cultivation of potted plants (NEAL; HENLEY, 1992). A high efficiency indicates that little water is lost through percolation, reducing the leaching of nutrients into the soil and reducing the potential of environmental contamination by salinization. The advantages and disadvantages of these technologies were described by Ferrarezi et al.
(2015). There are several types of subirrigation equipment available (FERRAREZI et al., 2015). The most widely used equipment is the ebb-and-flow bench (Figure 1E), in which the benches are filled with water up to $1 / 3$ of the container height.

Studies on using ebb-and-flow subirrigation for citrus production were started in Brazil in 2005 at the University of Campinas's School of Agricultural Engineering (Campinas, SP, Brazil), and have been providing critical information regarding the use of this system at a large scale. These studies include the determination of the relationship between the water level height and the water retention time in the substrate in subirrigation systems (FERRAREZI et al., 2017a), and the validation of operational parameters for the use of subirrigation benches (RIBEIRO et al., 2017). Studies on the effect of subirrigation on the production of citrus rootstock liners were described by Ferrarezi \& Testezlaf (2017a, 2017b). The results of these studies demonstrated that ebb-and-flow subirrigation could be successfully used to produce 'Rangpur' lime liners, shortening the crop cycle by 30 days by anticipating the time of transplantation for grafting and allowing for the production of Phytophthorafree trees compared to when trees were irrigated manually by overhead irrigation using breaker nozzles. The monitoring and operation of this system was also successfully automated using soil moisture sensors, meaning that it is a promising piece of technology for use in optimizing citrus nursery tree production.

Solis et al. (2016) compared subirrigation benches with sprinkler irrigation, drip irrigation, and capillary mats in Florida, USA, and observed similar production results among all methods, but greater water savings when using subirrigation than the other methods. However, the investment cost of drip irrigation is lower than those of subirrigation and manual irrigation. This is related to the lack of commercial equipment currently available for the application of subirrigation in citrus production and the high initial cost for infrastructure installation.

Irrigation of rootstocks and grafted trees: In addition to manual overhead irrigation, the most frequently used system for the production of nursery trees in citrus pots is drip irrigation using drippers with multiple outlets connected to microtubes, a system which is characterized by its simplicity of operation and maintenance (Figure 1E). This system can have one emitter with one- or multioutlet small tubes to route the water from the emitter to the trees. These small tubes are called distribution or spaghetti tubes and are usually $1 / 4$ or $1 / 8$ of an inch in diameter and made of polyethylene or soft vinyl (TESTEZLAF; FERRAREZI, 2017). 


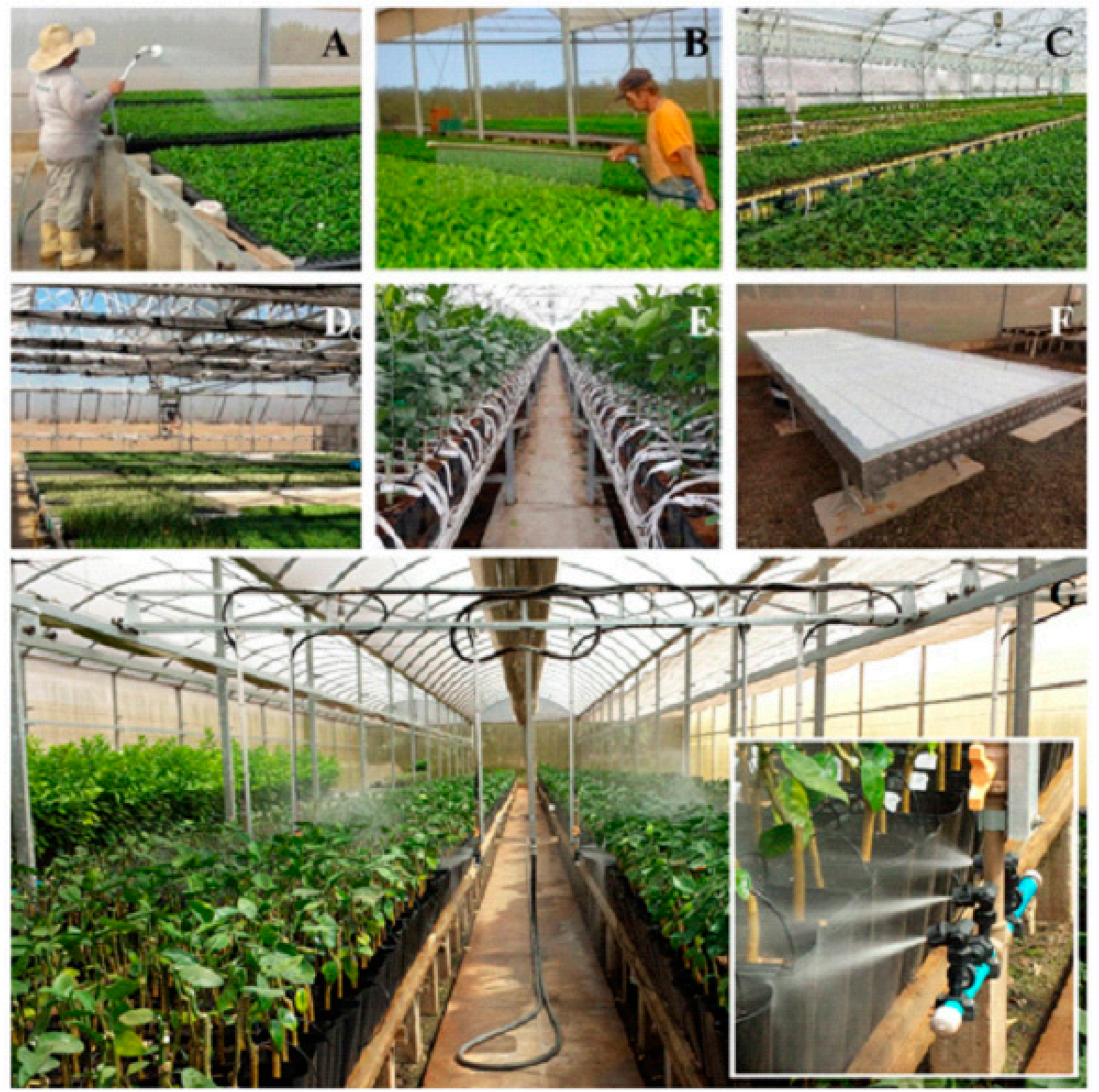

Figure 4. Irrigation systems used in commercial citrus nurseries for the production of rootstock seedlings, nursery trees and budstick in budwood increase blocks: A) shower head, hose nozzle or rain wand (Photo: Rhuanito Soranz Ferrarezi); B) perforated PVC pipes (Photo: Conan Ayade Salvador); C) micro sprinklers; D) spray bars; E) drip system; F) ebb-and-flow subirrigation (Photos: Rhuanito Soranz Ferrarezi) and G) Mobile bar in budwood block (Photo: Sérgio Alves de Carvalho).

A prototype of an automated mobile bar system was evaluated that presented efficiency in the addition of water and nutrients to budwood increase blocks maintained in pots (CARVALHO; NYSSEN, 2015; NYSSEN et al., 2016) (Figure 4G). Despite being an expensive system, this technology can drastically reduce labor cost in nurseries, and can also be adapted for the application of pesticides through chemigation. The water jets should be directed towards the trunk of the nursery tree to avoid wetting young leaves and branches and prevent the transmission of citrus canker (BELHLAU; BELASQUE $J R, 2014)$. Regulated deficit irrigation is another practice that presented promising results for citrus nursery tree production after grafting using a water potential threshold of $-15 \mathrm{kPa}$ in pine bark media (GIRARDI et al., 2018). 
Fertilization in seedbeds and pots or bags: After the introduction of the use of containers, soilless substrates, and protected environments in the production of citrus rootstocks and trees, several studies were performed to adjust fertilization guidelines to obtain better results with these techniques (CARVALHO; SOUZA, 1996; PERIN et al., 1999; CARVALHO et al., 2000b; BERNARDI et al., 2000; REZENDE et al, 1995; SERRANO et al., 2004; GIRARDI et al., 2005a; GIRARDI et al., 2010b; PRADO et al., 2008).

Bataglia et al. (2008) developed the fertilizer recommendations for citrus tree production in São Paulo state, Brazil, by monitoring factors that affected the plants' nutritional status using a system known as a 'Diagnosis and Recommendation Integrated System’ - DRIS (BEAUFILS,
1973). Chemical analyses of foliar macronutrient contents were carried out in a reference population, based on which DRIS indices were calculated and the optimum nutrition levels were determined for rootstocks and trees at different stages of development (Table 5).

The reference standards of Bataglia et al. (2008) indicated that 'Swingle' citrumelo requires higher concentrations of $\mathrm{N}, \mathrm{Mg}$, and $\mathrm{S}$ when compared to other rootstocks (Table 5). Grafted trees at the end of the first growth flush and before the final pruning also had higher $\mathrm{N}$ and K concentrations, demonstrating the shoot's ability to control nutrient demand. A similar study with 'Rangpur' lime and 'Swingle' citrumelo rootstocks ready for grafting in a commercial citrus nursery showed that DRIS is efficient at establishing regional criteria for nutrient sufficiency ranges (REZENDE et al., 2017).

Table 5. Foliar nutritional guidelines for rootstock liners of 'Rangpur' lime, 'Swingle' citrumelo, 'Cleopatra' and 'Sunki' mandarins, and grafted trees of 'Pera' sweet orange on 'Sunki' mandarin and 'Valencia' sweet orange on 'Swingle' citrumelo at the end of the first growth flush and before the final pruning. Adapted from Bataglia et al. (2008).

\begin{tabular}{|c|c|c|c|c|}
\hline \multirow[t]{2}{*}{ Nutrient } & \multicolumn{2}{|c|}{ Rootstock liners } & \multicolumn{2}{|c|}{$\begin{array}{c}\text { Grafted trees } \\
\text { 'Pera' on 'Sunki' and 'Valencia' on 'Swingle' }\end{array}$} \\
\hline & $\begin{array}{l}\text { 'Rangpur' } \\
\text { 'Cleopatra' and 'Sunki' }\end{array}$ & 'Swingle' & $\begin{array}{l}\text { End of the first growth } \\
\text { flush }\end{array}$ & Before the final pruning \\
\hline $\mathrm{N}$ & $25-35$ & $30-40$ & $35-40$ & $30-40$ \\
\hline$P$ & $2.0-2.5$ & $2.2-2.8$ & $2.2-2.8$ & $2.0-2.4$ \\
\hline $\mathrm{K}$ & $15-20$ & $16-22$ & $22-26$ & $21-28$ \\
\hline $\mathrm{Ca}$ & $20-30$ & $25-35$ & $16-23$ & $20-27$ \\
\hline $\mathrm{Mg}$ & $2.7-3.8$ & $3.5-4.5$ & $2.8-4.1$ & $2.3-3.5$ \\
\hline $\mathrm{S}$ & $2.5-3.5$ & $3.0-4.5$ & $2.5-3.5$ & $2.9-3.7$ \\
\hline B & $50-120$ & $90-150$ & $55-110$ & $90-170$ \\
\hline $\mathrm{Cu}$ & $5-30$ & $5-30$ & $5-30$ & $10-30$ \\
\hline $\mathrm{Fe}$ & $100-200$ & $100-200$ & $100-200$ & $120-250$ \\
\hline Mn & $50-200$ & $100-250$ & $40-200$ & $70-180$ \\
\hline $\mathrm{Zn}$ & $20-70$ & $25-70$ & $25-55$ & $40-90$ \\
\hline
\end{tabular}

Fertilization in nurseries uses granular, controlledrelease, and water-soluble fertilizers (during fertigation using separate tanks). In general, a fertilizer solution containing the following concentration (in $\mathrm{mg} / \mathrm{L}$ ) is considered balanced for the cultivation of citrus plants in substrate using fertigation: N (200), P (18), K (152), $\mathrm{Ca}$ (140), $\mathrm{Mg}$ (29), and S (21) (BATAGLIA et al., 2008). However, information on the chemical composition of the irrigation water and substrate is important to make appropriate adjustments to this nutrient solution and determine the concentrations of micronutrients that should be incorporated into the final fertilizer solution.

Positive effects of mineral nutrition on the growth of different rootstocks and grafted trees have been obtained with the use of arbuscular mycorrhizal fungi and other beneficial microorganisms (BOGAS et al., 2016; BACK et al., 2017; CARDOSO et al., 1993; OLIVEIRA et al., 1992; MELLONI; CARDOSO, 1999; FREITAS; AGUILAR-VILDOSO, 2004; WEBER et al., 1990). However, despite its great potential, especially for the current model of citrus tree production system using soilless substrates and greater environmental control, there have been no studies of the application of these methods at a larger scale that can serves as references for their evaluation, and thus their use is still restricted to a few commercial nurseries.

Management of vectors, pests, and diseases: The use of healthy trees produced in a protected environment 
is a fundamental component of the current integrated pest management used in citriculture. In Brazil, this system started in the late 1990s and early 2000s in the state of São Paulo (SÃO PAULO, 2005a; 2005b) as a preventive measure against the spread of $\mathrm{CVC}$, and in later years it was also extended to other states for the prevention of the CSD and HLB diseases. Current legal norms for the production of citrus nursery trees in São Paulo are available in São Paulo (2018a, 2018b, 2018c, 2018d).

Nursery trees must be free of CVC CSD, HLB, citrus canker, root-rot, and nematodes. These trees are regularly inspected and monitored, and contaminated trees are destroyed. Production in a protected environment does not on its own guarantee that pest- and disease-free trees will be grown, and a series of additional measures are necessary to guarantee the protection of trees in addition to those previously discussed under the topic of indexing. Although certain pests and diseases that affect citrus trees are not legally restrictive of their commercialization, they can still cause economic or aesthetic damages. Considering the high cost of production and the strict regulations of the citrus nursery industry, it is necessary to identify the occurrence of such problems early as a preventative measure. The maintenance of a small-scale analytical lab in the nursery and the strict control of agricultural inputs used in the nursery (irrigation water, fertilizer, substrate, seeds, budwood, and rootstocks) are decisive tools to avoid unexpected surprises.

The production of citrus trees in protected nurseries using anti-insect screens with $0.87 \times 0.30 \mathrm{~mm}$ mesh is the main preventive measure against diseases transmitted by insects. Target insects include: the Asian citrus psyllid, a vector of Candidatus Liberibacter spp. Jagoueix et al., the bacteria associated with HLB; leafhoppers of the subfamily Cicadellinae, which transmit Xylella fastidiosa Wells et al., 1987, the causal agent of CVC, especially Bucephalogonia xanthophis (Berg), which is more frequent in nurseries and among young plants; and the brown citrus aphid, Toxoptera citricida Kirkaldy, a vector of the CTV and CSD (PARRA et al., 2005).

Other measures have also been used to manage vectors in citrus nurseries, such as the use of yellow sticky traps in the antechambers to monitor the insects that enter there and the use of plastic in the nursery cover to block ultraviolet radiation, which may interfere with the ability of ACP to fly and find its host (MIRANDA et al., 2015). The drench application of imidacloprid and thiamethoxan systemic insecticides to the nursery trees a few days before planting them in the field controls ACP and other vectors for up to 90 days (SANCHES et al., 2009; MIRANDA et al., 2016).

The pests regularly found inside citrus nurseries include the citrus leafminer (Phyllocnistis citrella Stainton), broad mite [Polyphagotarsonemus latus (Banks)] that infests seedbeds at an especially high frequency,
Mexican mite [Tetranychus mexicanus (McGregor)], Texan mite [Eutetranychus banksi (McGregor)], citrus red mite [Panonychus citri (McGregor)], citrus rust mite [Phyllocoptruta oleivora (Ashmead)], citrus bud mite (Aceria sheldoni Ewing), green scale [Coccus viridis (Green)], citrus mealybug [Planococcus citri (Risso)], cottony cushion scale (Icerya purchasi Maskell), rufous scale [Selenaspidus articulatus (Morgan)], and slugs and snails (BREMER NETO et al., 2015; CARVALHO et al., 2005; RODRIGUES and OLIVEIRA, 2005). These pests require constant monitoring, since they depreciate the commercial value of the nursery trees. Fungus gnat (Bradysia spp.) flies are also a recurring problem in seedbeds as their very small, semi-transparent white larvae feed on the roots and root hairs of seedlings (CARVALHO et al., 2005).

Since root-rot (Phytophthora spp.), including Phytophthora nicotianae Breda de Haan (sin. P. parasitica) and P. citrophthora (R.E. Sm.; E.H. Sm.) Leonian (LARANJEIRA et al., 2005), is the most important disease in citrus nurseries, the citrus trees produced should be Phytophthora-free. Surveys carried out after the implementation of regulations to protect trees in São Paulo indicated that the spread of Phytophthora spp. root-rot can be significant in nurseries that do not use preventative control measures (SALVA, 2004; GRAHAM; FEICHTENBERGER, 2015). Some nurseries have small laboratories to analyze samples collected throughout the production cycle to monitor for the presence of diseases in substrate batches and in the nursery, promptly eliminating any possible sources of fungal inoculum. The most frequently used method is the bait test, given its simplicity and low cost (SIVIERO et al., 2002). Briefly, in this test the substrate samples are inserted into a plastic cup filled with disinfected water. Healthy leaf discs of citrus are placed on the surface of the water, and the glass is covered with plastic film and kept under constant artificial lighting. After one week, the disks are collected and analyzed under a microscope for the observation of any hyphae, sporangia, and zoospores of Phytophthora spp.

Other diseases that may occur in protected nurseries require rigorous preventive measures, including citrus canker (caused by Xanthomonas citri subsp. citri); damping-off (caused by Rhizoctonia solani Kühn, and in some cases by Pythium sp. and Fusarium sp.); albinism (caused by Alternaria tenuis Nees and Aspergillus flavus Link); 'Rangpur' lime and sour orange scab; Alternaria leaf spot (caused by Alternaria citri Ellis \& N. Pierce); citrus black spot; the citrus nematode Tylenchulus semipenetrans (Cobb); and the citrus root lesion nematodes Pratylenchus jaehni Inserra et al. and P. coffeae (Zimmermann) Goodey (LARANJEIRA et al., 2005; SANTOS et al., 2005).

Foliar spraying with metallic copper and other agrochemicals does not guarantee the health of the young trees, although some nurseries do this as a preventive 
measure. The disinfestation of vehicles, tools, equipment, and utensils used in the nursery with a quaternary ammonia solution is much more effective, as well as the disinfestation of hands and footwear and the use of clean clothing. Restricted staffing traffic and the use of healthy propagation materials (seeds, budwood, and rootstock liners) are essential. Other prevention measures include the use of localized irrigation, keeping the canopy as dry as possible, especially for such young susceptible tissues as new sprouts and graft shoots, to discourage the spread of the disease and reinfection. Trees should be kept away from the side screens to avoid rain splashes as well.

As discussed previously, the main substrates used in the production of citrus nursery trees have a base of composted pine bark and coconut fiber. Due to inadequate composting, macrofungi can be present in commercial batches. The basidiomycete Leucocoprinus birnbaumii (Corda) Singer is the most common, producing yellowcolored mushrooms, as well as other species, such as the dung-loving bird's nest mushroom Cyathus stercoreus (Schwein.) De Toni, the white or skullcap dapperling mushroom Leucocoprinus brebissonii (Godey) Locq., the false truffle Agariaceae incertae sedis, and the red mushroom Gymnopilus dilepis (Berk. \& Broome) Singer (AGUILAR-VILDOSO, 2009). These macrofungi generally do not cause direct damage to the citrus plants; however, they induce substrate hydrophobicity, which means the irrigation of the plants is not as effective, especially after transplanting them to the field, which can cause decreased plant growth and even tree death. Chemical control should be used in association with the manual elimination of fungal structures from the substrate.

Weeds should be avoided in the nursery because they shelter citrus pests, cause commercial depreciation, and compete for water and nutrients, reducing tree growth. Oxalis corniculata L. and Cardamine bonariensis Pers. are the most frequent weed species that grow on the same substrate as citrus nursery trees (ALVES, 2007). Manual weeding is preferred over the use of herbicides due to the risk of phytotoxicity to the citrus plants.

\section{Nursery management tools}

The management of a citrus nursery is a complex activity that involves planning, executing, monitoring, and adjusting a series of interconnected processes and activities. In addition to the technical processes inherent to citrus propagation related to cultural practices, integrated pest management, fertilization, and irrigation decisions, there are several administrative tasks involved, such as marketing, procurement, sales, inventory management, personnel hiring, leadership, and customer service.
The labor and input usage are the most important components in the cost management of nursery production (BREMER NETO et al., 2015). The demand for these factors depends on the evaluation of the production system and its technical efficiency indicators, which requires constant and accurate data collection and analysis. In addition to the production system, other relevant components of the management involve certification programs, which require a series of procedures to be undertaken by the nursery that often require a more professional management strategy (INSTRUÇÃO, 2017d).

The technical management of the nursery should be coordinated by integrated systems capable of generating reports. Computer software can be used to plan and monitor activities and to calculate production costs for professional business administration. Some programs are commercially available in the Brazilian market, ranging from apps developed by small nurserymen to complex systems created by specialized companies. The latter are usually adapted from those used in other farming activities, in particular for the management of orange production farms or nurseries of ornamental and other tree crops. Some examples of software adapted for use in citrus nurseries are those developed by Altec (Araras, SP, Brazil) (http://www.altec.inf.br) and by MasterPlanti (Curitiba, Paraná, Brazil) (http://www.masterplanti.com. br). Integrated computer-based information systems have been successfully developed for implementation in traceability and certification of the citrus nursery chains in Italy, and also serve as an example for the application of such systems in this industry segment in other citrusproducing regions (PORTO et al., 2011, 2014). 


\section{Final considerations}

The technological advances incorporated into citrus tree production in protected nurseries to exclude vectors of CTV, CVC, and most recently HLB, make it a formidable system for the production of high-quality trees for citriculture in Brazil, and in São Paulo state in particular. Among the main elements of this innovative system, we have highlighted its use of healthy basic materials and pathogen-free water and substrates, as well as the greater control of production processes, with benefits to tree health. The possibility of controlling environmental factors with the use of plastic covers and containers, and the adequate management of fertilizer, phytosanitation, and irrigation results in the production of rootstocks and grafted trees with outstanding quality in a shorter time in comparison to the traditional, unprotected field system. The easiness of selection and standardization of plants in containers, with transplanting performed without disturbing the root system, allows for the better survival of transplants in the field and planting year-round.

However, the production of citrus trees still presents several challenges despite the many recent technical advances made therein. The system used in São Paulo state has become a worldwide reference for citrus tree production, but it has yet to be implemented nationwide in Brazil. However, only its nationwide application will be able to adequately contain the dissemination and financial damage caused by diseases that threaten Brazilian citriculture, especially in regions with limited labor training.

In the coming years, the nursery industry should increase the use of automation in the different stages of basic material and tree production, with concurrent decreases in labor costs and lower risk to employees' health. Nurserymen should use micropropagation to accelerate the production of higher quality trees at lower cost. The availability of new technologies, such as different container types, especially related to those with a smaller capacity that combine the formation of high-performance nursery trees at less cost, as well as diversification and optimization of substrates, fertilizers, and products to control pests and diseases, are also necessary. The nursery industry needs to have access to new chemical and biological molecules to control pests and diseases, and modern kits for the determination of genetic origin and disease diagnostic tools for rapid and reliable on-site testing. Finally, it is necessary to improve the management systems applied in the nurseries.

The longstanding truth of the importance of citrus nursery trees, however, will remain unchanged with future innovations in nurseries: the nursery tree will continue to be the 'keystone of citriculture' (ROLFS; ROLFS, 1931).

\section{References}

AGUILAR-VILDOSO, C.I. Macrofungos em mudas cítricas. 2009. 182f. Tese (Doutorado em Genética e Melhoramento de Plantas), Escola Superior de Agricultura "Luiz de Queiroz", Universidade de São Paulo, Piracicaba, 2009.

ALMEIDA, C. O.; PASSOS, O. S. Citricultura Brasileira: em busca de novos rumos, desafios e oportunidades na região Nordeste. Cruz das Almas: Embrapa Mandioca e Fruticultura, 2011. 160p.

ALVES, A.S.R. Características biológicas, competição e susceptibilidade a herbicidas de plantas daninhas presentes em substratos utilizados para a produção de mudas cítricas. 2007. 63f. Dissertação (Mestrado em Fitotecnia), Escola Superior de Agricultura "Luiz de Queiroz”, Universidade de São Paulo, Piracicaba, 2007.

ANDERSON, C.M.; CASTLE, W.S.; MOORE, G.A. Isozymic identification of zygotic seedlings in Swingle citrumelo C. paradise x Poncirus trifoliate nursery and field populations. Journal of the American Society for Horticultural Science, Alexandria, v.116, n.2., p.322326, 1991.

ANDRADE, R. A. de; MARTINS, A., B.G. Propagação vegetativa de porta-enxertos para citros. Revista Brasileira de Fruticultura, Jaboticabal, v.25, n.1, p.134136, 2003.

ANDRADE, R.A.A.; MARTINS, A.B.G.; LEMOS, E.G.M.; LUZ, F.J.F.; SILVA, M.T.H. Detecção de polimorfismo em porta-enxertos para citros. Revista Brasileira de Fruticultura, Jaboticabal, v.29, n.2, p. 345-349, 2007.

ANDRADE-RODRIGUEZ, M.; VILLEGAS-MONTER, A.; CARRILlO-CASTANEDA, G.; GARCIAVELAZQUEZ, A. Polyembryony and identification of Volkamerian lemon zygotic and nucellar seedlings using RAPD. Pesquisa Agropecuária Brasileira, Brasília, v.39, n.6, p.551-559, 2004.

ANUÁRIO BRASILEIRO DA FRUTICULTURA 2018: Brazilian Fruit Yearbook. Editora Gazeta, Santa Cruz do Sul, 2018. 88p. il. Disponivel em:http://www. editoragazeta.com.br/flip/anuario-fruticultura-2018/ files/assets/basic-html/index.html\#1. Acessado em 20 de dezembro de 2018. 
ARAÚJO, P. S R.; MOURAO FILHO, F. DE A. A.; SILVA, J. A. F.; BARBANO, M.T. Enraizamento de estacas de limeira ácida 'Tahiti' coletadas em diferentes posições na árvore. Scientia Agricola, Piracicaba, v.56, n.2, p.357-361, 1999.

ASHARI, S.; ASPINALL, D.; SEDGLEY, M. Discrimination of zygotic and nucellar seedlings of five polyembryonic citrus rootstocks by isozyme analysis and seedling morphology. Journal of Horticultural Science, v.63, p.695-703, 1988.

AZEVEDO, F.A., PACHECO, C.A., SCHINOR, E.H., CARVALHO, S.A. CONCEIÇÃO, P.M. Produtividade de laranjeira Folha Murcha enxertada em limoeiro Cravo, sob adensamento de plantio. Bragantia, Campinas, v. 74, n.2, p.184-188, 2015.

AZEVEDO, F.A.; POLYDORO, D.A.; BASTIANEL, M.; KUPPER, K.C.; STUART, R.M.; COSTA, F.P.; PIO, R.M. Resposta de diferentes genótipos de tangerinas e seus híbridos à inoculação in vitro e in vivo de Alternaria alternata. Revista Brasileira de Fruticultura, Jaboticabal, v.32, n.01, p.1-10, 2010.

BACK, M.M.; REITH, S.; GIULIANI, J.C.; SOUZA, P.V.D. Interação entre porta-enxertos de citros e fungos micorrízicos arbusculares Iheringia, Série Botânica, Porto Alegre, v.72, n.2, p.277-282, 2017.

BAR-JOSEPH, M.; ROBERTSON, C.; HILF, M.E.; DAWSON, W.O. A novel method for Citrus propagation: Seed grafting. Journal of Horticultural Science \& Biotechnology, London, v.86, n.6, p.616-618, 2011.

BASTIANEL, M.; SIMONETTI, L.M. SCHINOR, E.H.; DE GIORGI, R.O.; DE NEGRI, J.D.; GOMES, D.B.; AZEVEDO, F.A. Avaliação do banco de germoplasma de mexericas com relação às características físico químico e suscetibilidade à mancha marrom de alternaria. Bragantia, Campinas, v.73, n.1, p.23-31, 2014.

BASTOS, D.C.; FERREIRA, E.A.; PASSOS, O.S.; SÁ, J.F.; ATAÍDE, E.M.; CALGARO, M. Cultivares copa e porta-enxertos para a citricultura brasileira. Informe Agropecuário, Belo Horizonte, v.35, n.281, p.36-45, 2014.

BATAGLIA, O.C.; FURLANI, P.R.; FERRAREZI, R.S.; MEDINA, C.L. Padrão nutricional de mudas de citros. Araraquara: Vivecitrus/Conplant, 40p. 2008 (Boletim Técnico). ISBN 978-85-62812-00-2. URL: http://www. conplant.com.br/wp-content/uploads/2010/06/Boletim Vivecitrus_Conplant.pdf.
BEAUFILS, E.R. Diagnosis and Recommendation Integrated System (DRIS). A general scheme of experimentation and calibration based on principles developed from research in plant nutrition. Pietermaritzburg, South Africa: University of Natal, p.132, 1973 (Soil Science Bulletin, 1).

BEESON JR., R.C.; SILVA, D. Development of a procedure to maximize production of hardy rootstocks of citrus using stem cuttings. American Journal of Plant Sciences, Wuhan, v.8, p.2837-2846, 2017a. DOI: 10.4236/ ajps.2017.811192.

BEESON JR., R.C.; SILVA, D. Propagation of citrus rootstock cuttings success depends on season. Journal of Horticulture, Foster City, v.4, n.4, 213, 2017b. DOI: 10.4172/2376-0354.1000213.

BEHLAU, F.; BELASQUE JUNIOR, J. Cancro cítrico: a doença e seu controle. Araraquara-SP: Fundecitrus. 2014. 82p.

BERNARDI，A.C.C.; CARMELLO，Q.A.C.; CARVALHO, S.A. Desenvolvimento de mudas de citros cultivadas em vaso em resposta à adubação NPK. Scientia Agricola, Piracicaba, v.57, n.4, p.733-738, 2000.

BLUMER, S.; POMPEU JR., J. Avaliação de citrandarins e outros híbridos de trifoliata como porta-enxertos para citros em São Paulo. Revista Brasileira de Fruticultura, Jaboticabal, v. 27, n.2, p. 264-267, 2005.

BOGAS, A.C.; AGUILAR-VILDOSO, C.I.; CAMARGONEVES, A.A.; ARAUJO, W.L. Effects of growthpromoting endophytic Methylobacterium on development of Citrus rootstocks. African Journal of Microbiology Research, Sapele, v.10, n.19, p.646-653, 2016.

BORDAS, M.1, REDONDO, A., BAPTISTA, L.; TORRENTS, J. Efficient commercial micropropagation of new citrus rootstocks. In: INTERNACIONAL CITRUS CONGRESS. INTERNATIONAL SOCIETY OF CITRICULTURE, Foz do Iguaçu-PR - Brazil September 18 - 23, 2016. Abstract Book... p.99. Scientific Session 7130.

BORGES, R. de S; ALMEIDA, F. J.; SCARANARI, C.; MACHADO, M.A; CARVALHO, S.A.; COLETTAFILHO, H.D.; AGUILAR-VILDOSO, C.I. Programa IAC/Embrapa/CNPq de incentivo à produção de mudas de citros isentas de CVC e outras doenças. Laranja, Cordeirópolis, v.21, n.1, p.205-224, 2000.

BORGES, R.S.; OLIVEIRA, R.P.; PIO, R.M.; FARIA, A.P. 2009. Catálogo de Cultivares de Citros de Mesa 2009. Embrapa, Pelotas, RS, Brazil. 2009. 52 p. (Embrapa Clima Temperado. Documentos, 266) 
BORGES, R.S.; PIO, R.M. Comparative study of the mandarin hybrid fruit characteristics: Nova, Murcott and Ortanique in Capão Bonito-SP, Brazil. Revista Brasileira de Fruticultura, Jaboticabal, v.25, n.3, p.448-452, 2003.

BOTEON, M; NEVES, E.M. Citricultura brasileira: aspectos econômicos. In: MATTOS JR., D. et al. Citros. Campinas, Instituto Agronômico/Fundag, 2005. Cap.2, p.19-36.

BRAR, G.R.P.S.; SPANN, T.M. Photoperiodic phytochrome-mediated vegetative growth responses of container-grown citrus nursery trees. Scientia Horticulturae, New York, v.176, p.112-119, 2014.

BREMER NETO, H.; MOURÃO FILHO, F. A. A.; STUCHI,E. S.; ESPINOZA-NÚÑEZ, E.; CANTUARIASAVILÉS, T.E. The horticultural performance of five 'Tahiti' lime selections grafted onto 'Swingle' citrumelo under irrigated and non-irrigated conditions. Scientia Horticulturae, New York, v.150, p.181-186, 2013.

BREMER NETO, H.; SILVA, S.R.; MOURÃO FILHO, F.A.A.; SPOSITO, M.B.; CAPUTO, M.M. Manual de boas práticas para produção de mudas cítricas. Araraquara, Vivecitrus, 2015. 69p.

BRUYERE, S; LURO, F.; FROELICHER, Y.; MORILLON, R.; OLLITRAULT, P. Poncirus phylogenetic diagnotic snps markers are useful to analyse zygotic rates in diploid and tetraploid citrus $\mathrm{x}$ poncirus rootstock seedlings. In: INTERNACIONAL CITRUS CONGRESS. Interntional Society of Citriculture, Foz do Iguaçu-PR Brazil September 18 - 23, 2016. Abstract Book... p.99. Scientific Session 10266.

BULLETIN OEPP/EPPO PM 7/121 (1). Diagnostic protocols for regulated pests: Candidatus Liberibacter africanus', 'Candidatus Liberibacter americanus' and 'Candidatus Liberibacter asiaticus' Bulletin OEPP/EPPO Bulletin 44, 376-389, 2014.

BULLETIN OEPP/EPPO PM 7/24 (2). Diagnostic protocols for regulated pests: Xylella fastidiosa. Bulletin OEPP/EPPO Bulletin 46, p.463-500. 2016.

\section{BULLETIN OEPP/EPPO PM 7/31 (1). Diagnostic} protocols for regulated pests: Citrus tristeza closterovirus. Bulletin OEPP/EPPO Bulletin 34, 239 $-246.2004$.

CANTUARIAS-AVILÉS, T. E.; MOURÃO FILHO, F. A. A.; STUCHI, E. S.; SILVA, S. R.; ESPINOZA-NÚÑEZ, E.; BREMER NETO, H. Rootstocks for high fruit yield and quality of 'Tahiti' lime under rain-fed conditions. Scientia Horticulturae, New York, v.142, p.105-111, 2012.
CANTUARIAS-AVILÉS, T.E.; MOURÃO FILHO, F.A.A.; STUCHI, E.S.; SILVA, S.R.; ESPINOZANÚÑEZ, E. Tree performance and fruit yield and quality of 'Okitsu' Satsuma mandarin grafted on 12 rootstocks. Scientia Horticulturae, New York, v.123, p.318-322, 2010.

CAPUTO, M.M.; MOURÃO FILHO, F. de A.A.; SILVA, S.R. da; BREMER NETO, H.; COUTO, H.T.Z. do; STUCHI, E.S. Seleção de cultivares de laranja doce de maturação precoce por índices de desempenho. Pesquisa Agropecuária Brasileira, Brasília, v.47, n.11, p.16691672, 2012.

CARDOSO, E. J. B. N.; LAMBAIS, M. R. Efeito da Aldicarb e Fosetil-Al no desenvolvimento e na colonização micorrízica de tangerina Cleópatra. Revista Brasileira de Ciência do Solo. Viçosa, v.17, n.2, p.179-184, 1993.

CARIMI, F.; DE PASQUALE, F. Micropropagation of Citrus. In: JAIN, S.M.; ISHII, K. (Eds.). Micropropagation of Woody Trees and Fruits. Dortrecht: Kluwer Academic Publishers, p.589-619. 2003.

CARVALHO, H.W.L.; MARTINS, C. R.; TEODORO, A.V.; SOARES FILHO, W.S.; PASSOS, O.S. Agronomical performance of 'Piemonte' mandarin grafted on several rootstocks in the Brazilian Coastal Tablelands. Pesquisa Agropecuária Brasileira, Brasília, v.51, n.11, p.18301838, 2016a.

CARVALHO, J.A. VON PINHO, E.V.R; OLIVEIRA, J.A.; GUIMARÃES, R.M.; BONOME, L.T. qualidade de sementes de limão-cravo (Citrus limonia Osbeck) durante o armazenamento. Revista Brasileira de Sementes, Londrina, v.24, p.286-298, 2002.

CARVALHO, L.M.; CARVALHO, H.W.L.; SOARES FILHO, W.S; MARTINS, C.R.; PASSOS, O.S. Portaenxertos promissores, alternativos ao limoeiro 'Cravo', nos Tabuleiros Costeiros de Sergipe. Pesquisa Agropecuária Brasileira, Brasília, v.51, n.2, p. 132-141, 2016 b.

CARVALHO, S.A. A produção de mudas fiscalizadas e certificadas de citros. Visão Agrícola, Piracicaba, v.1, n.2, p.8-10, 2004.

CARVALHO, S.A. Atualização sobre Programas de Matrizes e Certificação de Citros do Estado de São Paulo. Espaço Citricola - Revista Eletrônica de Citricultura, v.9, n.57, p.15-27, 2014. Disponível em: http://www. espacocitricola.eng.br/site/index.php/artigos/file/16espaco-57. (Acessado em 12/04/2017). 
CARVALHO, S.A. Caracterização do sistema radicular do limoeiro 'Cravo' propagado pela técnica in vitro. In: CONGRESSO DA PÓS-GRADUAÇÃO DA ESAL, 5., Lavras-MG, 1992. Anais... Lavras: Associação de PósGraduandos da ESALQ, 1992. p.105.

CARVALHO, S.A. Estratégias para estabelecimento de matrizes, borbulheiras e viveiro de citros em ambiente protegido. In: SEMINÁRIO INTERNACIONAL DE CITROS - TRATOS CULTURAIS, 5, 1998. Bebedouro. Anais... Campinas: Fundação Cargill, 1998. p.67-101.

CARVALHO, S.A., NUNES, W.M.C.; BELASQUE JR, J.; CROCE FILHO, J., MACHADO, M.A.; BOCK, C.; ABDO, Z. Comparison of resistance to Asiatic citrus canker among different genotypes of Citrus spp. in a longterm canker-resistance screening experiment in Brazil. Plant Disease, Ames, v.99, n.2, p.207-218, 2015a.

CARVALHO, S.A.; ALARCON, P.A.S.; PASQUAL, M.; PINTO, J.E.B.P.; ISHIDA, J.S. Efeito do IBA e ANA no enraizamento in vitro do porta-enxerto limoeiro Cravo (Citrus Limonia Osbeck). In: II NATIONAL FAIR AMD CONGRESS OF BIOTECHNOLOGY AND I LATIN-AMERICAN FAIR AND CONGRESS OF BIOTECHNOLOGY, São Paulo, 1991. Resumos... ABRABI, São Paulo, 1991. p.I-3.

CARVALHO, S.A.; DE NEGRI, J; MÜLLER, G.W; POMPEU JR., J. Inter-enxertia e ocorrência de tristeza capão bonito em laranja Pera IAC 2000. Tropical Plant Pathology, Brasília, v.36 (suplemento), agosto 2011. (1 CD Room, p.1267).

CARVALHO, S.A.; GRAF, C.C.D.; VIOLANTE, A.R. Produção de material básico e propagação. In: MATTOS JR., D.; DE NEGRI, J.D.; PIO, R.M.; POMPEU JR., J. (Ed.). Citros. Campinas: Instituto Agronômico; Fundag, 2005. p.279-316.

CARVALHO, S.A.; LARANJEIRA, F.F. Protótipo de viveiro de mudas certificadas e borbulheiras sob telado à prova de afídeos do Centro de Citricultura. Laranja, Cordeirópolis, v.15, n.2, p.213-220, 1994.

CARVALHO, S.A.; MACHADO, M.A. Forçamento de borbulhas na produção de mudas cítricas envasadas. Revista Brasileira de Fruticultura, Cruz das Almas, v.19, n.3, p.359-364, 1997.

CARVALHO, S.A.; MACHADO, M.A.; MÜLLER, G.W.; COLETTA-FILHO, H. 2001. Produção de borbulha básica para formação de mudas de citros sadias em São Paulo. Laranja, Cordeirópolis, v.22, n.1, p.185-201, 2001a.
CARVALHO, S.A.; MÜLLER, G.W.; POMPEU JR.; J.; CASTRO, J.L. Transmissão do agente da enação das nervuras-galha lenhosa dos citros por Toxoptera citricidus. Fitopatologia Brasileira, Brasília, v.26, n.1, p.95-98 2001b.

CARVALHO, S.A.; NYSSEN, D. Pesquisa Aplicada: Irrigação automatizada em viveiros e borbulheiras. Informativo Centro de Citricultura, Cordeirópolis, v.15, n.246, p.4, 2015.

CARVALHO, S.A.; SANDRINI, M.; TAVARES, E.D.; SILVA, L.F.C.; ROCHA, A.C. Tratamento pós-colheita de ramos porta-borbulhas de citros. Pesquisa Agropecuária Brasileira, Brasília, v.24, n.8, p.1041-1-43, 1989.

CARVALHO, S.A.; SANTOS, F.A.; MACHADO, M.A. Avaliação para viroses de variedades de citros em introdução no banco ativo de germoplasma de citros do IAC. In: CONGRESSO BRASILEIRO DE FITOPATOLOGIA, Uberlândia, SBF, 2003. Resumos Expandidos... Uberlândia: SBF, 2003. (1 cd room). CARVALHO, S.A.; SETIN, D.W. Propagação comercial de plantas citricas. Informe Agropecuário, Belo Horizonte, v.35, n.281, p.46-53, 2014.

CARVALHO, S.A.; SILVA, J.A.; SEMPIONATO, O.R. Produção de borbulhas certificadas de citros no Estado de São Paulo. Ed. FUNEP (Jaboticabal), 2000a, 26p.

CARVALHO, S.A.; SILVA, L.F.C. Monitoring the viability of citrus rootstocks seeds stored under refrigeration. Revista Brasileira de Fruticultura, Jaboticabal, v.35, n.1, p.338-345, 2013.

CARVALHO, S.A.; SOUZA, M. Doses e frequencia de aplicação de nitrato de potássio no crescimento do limoeiro 'Cravo' e da tangerineira 'Cleópatra' em bandejas. Pesquisa Agropecuária Brasileira, Brasília, v.31, n.11, p.815-822, 1996.

CARVALHO, S.A.; SOUZA, M.; MATTOS JR., D. Efeito do $\mathrm{KNO}_{3}$ nos teores de macronutrientes na matéria seca total de porta-enxertos cítricos produzidos em bandejas. Bragantia, Campinas, v.59, n.1, p.89-94, 2000b.

CARVALHO, S.A; LATADO, R.R.; SILVA, L.F.C.; MÜLLER, G.W. Agronomic performance of thirty two clones of 'Pera' sweet orange in São Paulo state, Brazil. Acta Horticulturae, n.1065, p.281-291, 2015 b.

CASTLE W.S. Fibrous root distribution of 'Pineapple' orange trees on rough lemon rootstock at three tree spacing. Journal of the American Society of Horticultural Scicience, v.105, n.3, p.478-480, 1980. 
CASTLE, W.S.; TUCKER, D.P.H.; KREZDORN, A.H.; YOUTSEY, C.O. Rootstocks for Florida Citrus. University of Florida, Gainesville.1993. 92p.

CASTLE, W.S.; YOUTSEY, C.O. Root system characteristics of citrus nursery trees. Proceedings of the Florida State Horticultural Society, Orlando, v.90, p.39-44, 1977.

CAVALCANTE, I.H.L., MARTINS, A.B.G.; STUCHI, E.S.; CAMPOS, M.C.C. Fruit maturation as a parameter for selection of sweet orange cultivars in Brazil. Journal of Food, Agriculture \& Environment, v.7, n 3-4, 2009.

COLETTA-FILHO, H.D., MACHADO, M.A., TARGON, M.L.P.N.; MOREIRA, M.C.P.Q.D.G,; POMPEU JR., J. Analysis of phylogenetic diversity among mandarins (Citrus spp) using RAPD markers. Euphytica, Wageningen, v.102, n.1, p.133-139, 1998.

COLETTA-FILHO, H.D., POMPEU JR., J.; MACHADO, M.A. Certificação genética de porta-enxertos de citros: dados de 2003. Laranja, Cordeirópolis, v.25, n. 1, p.171$178,2004$.

CONCEIÇÃO, P.M.; AZEVEDO, F.A.; HENDRIKX, W.; MARTINELLI, R.; PACHECO, C.A.; CARVALHO, S.A. Qualidade de sementes de porta-enxertos de citros do Jardim Clonal do Centro APTA Citros Sylvio Moreira/ IAC. Citrus Research \& Technology, Cordeirópolis, v.36, n.1, p.9-14, 2015.

CRISTOFANI, M.; MACHADO, M.A. Utilização de marcadores moleculares na identificação de plântulas zigóticas e nucelares em sementeiras de limão 'Cravo'. Laranja, Cordeirópolis, v.19, n.1, p.159-66, 1998.

CRISTOFANI-YALI, M.; BASTIANEL, M.; FALDONI, L.; BLUMER, S.; POMPEU JR., J.; CAMPOS, T.M.P ; SANTOS JUNIOR, J. A.; MACHADO, M.A. Seleção de citrandarins (Tangerina Sunki vs. Poncirus trifoliata) para porta-enxertos de citros. Laranja, Cordeirópolis, v.28, n.1-2, p.71-79, 2007.

CRISTOFANI-YALY, M. IAC 2019Maria. Informativo Centro de Citricultura. Cordeirópolis, Junho de 2017, Especial, 2p (Folder Técnico).

CRISTOFANI-YALY, M.; FIGUEIREDO, J.O.; TARGON, M.L.P.N.; MACHADO, M.A. Diferenciação de variedades de limão utilizando microssatélites. Laranja, Cordeirópolis, v.24, n.1, p.165-175, 2003.
CRISTOFANI-YALY，M.; NOVELLI，V.M.; BASTIANEL, M.; MACHADO, M.A. Transferability and level of heterozygosity of microsatellite markers in Citrus species. Plant Molecular Biology Reporter, v.29, n.2, p-418-423, 2011.

CUNHA SOBRINHO, A.P. da; SOARES FILHO, W. dos S.; PASSOS, O.S. Porta-enxertos para laranja 'Pêra' (Citrus sinensis (L) Osbeck) na região de Cruz das Almas, Bahia. Revista Brasileira de Fruticultura, Cruz das Almas, v.2, n.3, p.21-32, 1980.

DAVIES, F.S.; ALBRIGO, L.G. Citrus. CAB International. 1994. 254p.

DECRETO No 5.153, DE 23 DE JULHO DE 2004. Aprova o Regulamento da Lei $\mathrm{n}^{\mathrm{o}} 10.711$, de 5 de agosto de 2003, que dispõe sobre o Sistema Nacional de Sementes e Mudas - SNSM. Disponivel em: http://www.planalto. gov.br/ccivil_03/_ato2004-2006/2004/decreto/d5153.htm. Acessada em 25 ago. 2017.

DONADIO, L.C.; FIGUEIREDO, J.O.; PIO, R.M. Variedades cítricas brasileiras. Jaboticabal, FUNEP, 1995228 .

EED, A. M., BEGUM, H. SIVARAMAKRISHNAN, S., DA SILVA, J.A.T., AMRENDER-REDDY, S.; ALGABAL, A.Q. Rapid protocol for in vitro multiplication of Citrus limonia Osbeck Rootstock. International Journal of Plant Developmental Biology, Prague, v.5, n.1., p.78-82. 2011.

EIRAS, M.; SILVA, S.R.; STUCHI, E.S.; TARGON, M.L.P.N.; CARVALHO, S.A. Viroides em citros. Tropical Plant Pathology, Brasília, v.34, n.5, p.275-296, 2009.

EMBRAPA RECURSOS GENÉCOS E BIOTECNOLOGIA. Carta de Serviços./Embrapa Recursos Genécos e Biotecnologia. - Brasília-DF: Embrapa Recursos Genéticos e Biotecnologia 41p. 2016. Disponível em: http:/www.embrapa.br/recursosgeneticos-e-e-biotecnologia (Acessado em 31/07/2017).

ESAU, K. Anatomy of seed plants. California: John Wiley \& Sons, 1977. 550p.

ESPINOZA-NUÑEZ, E.; MOURÃO FILHO, F. A. A.; STUCHI, E. S.; CANTUARIAS-AVILÉS, T. E.; DIAS, T. S. Performance of 'Tahiti' acid lime on twelve rootstocks under irrigated and non-irrigated conditions. Scientia Horticulturae, New York, v.129, p.227-231, 2011.

ESTIMATIVA da safra de laranja 2017/18 do cinturão citrícola de São Paulo e Triângulo/Sudoeste mineiro: cenário de maio de 2017. Fundecitrus, Araraquara, 2017. $26 \mathrm{p}$. 
EUROPEAN AND MEDITERRANEAN PLANT PROTECTION ORGANIZATION EPPO. Citrus vein enation 'virus'. Disponível em: http://www.eppo.int/ QUARANTINE/data_sheets/virus/CVEV00_ds.pdf (Acessado em 21/08/2017).

FADEL, A.L.; STUCHI, E.S.; CARVALHO, S.A.; FEDERICI, M.T.; COLETTA-FILHO, H.D. Navelina ISA 315: A cultivar resistant to citrus variegated chlorosis. Crop Protection, London, v. 64, n.1, p.115-121, 2014.

FERRAREZI, R.S.; FERREIRA FILHO, A.C.; TESTEZLAF, R. Altura de lâmina e tempo de permanência de água na umidade de substratos em subirrigação. Horticultura Brasileira, Brasília, v.35, n.2, p.186-194, 2017 a.

FERRAREZI, R.S.; TESTEZLAF, R. Automated ebband-flow subirrigation for citrus liners production. I. Plant growth. Agricultural Water Management, v.192, p.45-57, 2017a.

FERRAREZI, R.S.; TESTEZLAF, R. Automated ebb-andflow subirrigation for citrus liners production. II. Pests, diseases and nutrient concentration. Agricultural Water Management, v.192, p.21-32, 2017b.

FERRAREZI, R.S.; WEAVER, G.M.; VAN IERSEL, M.W.; TESTEZLAF, R. Subirrigation: Historical overview, challenges, and future prospects. HortTechnology, Alexandria, v.25, n.3, p.262-276, 2015.

FERRAREZI, R.S.; WRIGHT, A.L.; BOMAN, B.J.; SCHUMANN, A.W.; GMITTER, F.G.; GROSSER, J.W. Protected fresh grapefruit cultivation systems: Antipsyllid screen effects on environmental variables inside enclosures. HortTechnology, Alexandria, v.27, n.5, p.665-671, $2017 \mathrm{~b}$.

FIGUEIREDO, J.O. Variedades copa de valor comercial. In: RODRIGUEZ, O.; VIÉGAS, F.; POMPEU JR., J.; AMARO, A.A. Citricultura Brasileira, Campinas-SP, Fundação Cargill, 1991. v.1. p.228-264.

FOCHESATO, M.L.; SOUZA, P.V.D.; SCHÄFER, G.; MACIEL, H.S. Crescimento vegetativo de porta-enxertos de citros produzidos em substratos comerciais. Ciência Rural, Santa Maria, v.37, n.4, p.970-975, 2007.

FRANÇA, N. O.; AMORIM, M. S.; GIRARDI, E. A.; PASSOS, O. S.; SOARES FILHO, W. S. Performance of 'Tuxpan Valencia' sweet orange grafted onto 14 rootstocks in northern Bahia, Brazil. Revista Brasileira de Fruticultura, Jaboticabal, v.38, n.4, e-684, 2016.
FREITAS, S.S.;AGUILAR-VILDOSO, C.I. Rizopromoção do crescimento de plantas cítricas. Revista Brasileira de Ciência do Solo, Viçosa, v.28, n.6, p.987-994, 2004.

GIRARDI, E.A.; MOURÃO FILHO, F.A.A.; ALVES, A.S.R. Use of the heat dissipation method for sap flow measurement in citrus nursery trees. Revista Brasileira de Fruticultura, Jaboticabal, v.32, n.4, p.976-983, 2010 a.

GIRARDI, E.A.; MOURÃO FILHO, F.A.A.; DELGADOROJAS, J.S.; ARAUJO, J. P.C. Mudas de laranjeira 'Valência' sobre dois porta-enxertos e sob diferentes manejos de adubação. Revista Brasileira de Fruticultura, Jaboticabal, v.32, n.3, p.855-864, 2010b.

GIRARDI, E.A.; MOURÃO FILHO, F.A.A.; GRAF, C.C.D.; OLIC, F.B. Influence of Soluble and SlowRelease Fertilizers on Vegetative Growth of Containerized Citrus Nursery Trees. Journal of Plant Nutrition, Philadelphia, v.28, n.9, p.1465-1480, 2005 a.

GIRARDI, E.A.; MOURÃO FILHO, F.A.A.; GRAF, C.C.D.; OLIC, F.B. Vegetative growth of citrus nursery trees related to the container volume. Fruits (Paris), Montpellier, v.60, n.2, p.101-105, 2005 b.

GIRARDI, E.A.; MOURÃO FILHO, F.A.A.; KLUGE, R.A. Effect of seed coat removal and controlled-release fertilizer application on plant emergence and vegetative growth of two citrus rootstocks. Fruits, (Paris), Montpellier, v.62, n.1, p.13-19, 2007a.

GIRARDI, E.A.; MOURÃO FILHO, F.A.A.; PIEDADE, S.M.S. Desenvolvimento vegetativo e custo de produção de porta-enxertos de citros em recipientes para fins de subenxertia. Pesquisa Agropecuária Brasileira, Brasília, v.42, n.5, p.679-687, 2007b.

GIRARDI, E.A.; STUCHI, E.S.; PASSOS, O.S.; SOARES FILHO, W.S.; PAROLIN, L.G.; REIFF, E. T.; SEMPIONATO, O.R.; DOBRE, R.P. Minimudas: produção de mudas de citros em recipientes pequenos. Cruz das Almas: Embrapa Mandioca e Fruticultura, 2017 (Circular Técnica 123).

GIRARDI. E.A.; MOURÃO FILHO, F.A.A. Production of interstocked 'Pera' sweet orange nursery trees on 'Volkamer' lemon and 'Swingle' citrumelo rootstocks. Scientia Agricola, Piracicaba, v.63, n.1, p.5-10, 2006.

GIRARDI, E. A.; BRANDÃO, A. D.; COELHO, R. D.; COUTO, H. T. Z.; BUCKERIDGE, M. S.; MOURÃO FILHO, F. A. A. Regulated deficit irrigation benefits the production of container-grown citrus nursery trees. TreesStructure and Function, Berlin, v.32, n.6, p.1751-1766, 2018. 
GRAHAM, J.; FEICHTENBERGER, E. Citrus phytophthora diseases: Management challenges and successes. Journal of Citrus Pathology, Riverside, v.2, n.1, p.1-11, 2015.

GREVE, A.; PRATES, H.S.; MÜLLER, G.W. Produção de borbulhas certificadas de citros no Estado de São Paulo. In: RODRIGUEZ, O. et al. (Ed.). Citricultura brasileira. 2.ed. Campinas: Fundação Cargill, 1991. v.1, p.302-317.

HALL, D.G. An assessment of yellow sticky card traps as indicators of the relative abundance of adult Diaphorina citri in citrus. Journal of Economic Entomology, Lanham, v.102, p.446-452, 2009.

HASSE, G. A laranja no Brasil 1500-1987: a história da agroindústria cítrica brasileira, dos quintais coloniais às fábricas exportadoras de suco do século XX. São Paulo: Duprat \& Iobe, 1987.

HAYASHI, S.; GIRARDI, E.A.; SILVA, S. R.; STUCHI, E.S.; CANTUARIAS-AVILÉS, T. Avaliação de fita fotodegradável para enxertia em mudas de citros. Revista Brasileira de Fruticultura, Jaboticabal, v.34, n.2, p.641645, 2012.

HUSSAIN, S.; CURK, F.; DHUIQUE-MAYER, C.; URBAN, L.; OLLITRAULT, P.; LURO, F.; MORILLON, F. Autotetraploid trifoliate orange (Poncirus trifoliata) rootstocks do not impact clementine quality but reduce fruit yields and highly modify rootstock/scion physiology. Scientia Horticulturae, New York, v.134, p.100-107, 2012.

IBPGR Descriptors for Citrus. Rome, International Board for Plant Genetic Resources. 1998. 27p.

INFORMATIVO CENTRO DE CITRICULTURA. Nova doença já causa prejuízos a pomares de SP e MG. Informativo Centro de Citricultura, Cordeirópolis, v.76, p.1-4, 2001.

INFORMATIVO CENTRO DE CITRICULTURA. Pesquisa aplicada: limpeza clonal e plantas básicas. Cordeirópolis, v.262, p.2, 2017.

INSTITUTO BRASILEIRO DE GEOGRAFIA E ESTATÍSTICA - IBGE. Levantamento Sistemático da Produção Agrícola, Janeiro 2018. Disponível em: https:// www.ibge.gov.br/estatisticas-novoportal/economicas/ agricultura-e-pecuaria/9201-levantamento-sistematicoda-producao-agricola.html? \&t=resultados. Acessado em 20 de dezembro de 2018.
INSTRUÇÃO NORMATIVA N ${ }^{\circ} 22$, DE 27 DE AGOSTO DE 2012. Normas para a Produção e a Comercialização de Mudas e de Outras Estruturas de Propagação obtidas por meio de Cultura de Tecidos de Plantas. Disponível em: http:// www.agricultura.gov.br/assuntos/insumos-agropecuarios/ insumos-agricolas/sementes-e-mudas/publicacoessementes-e-mudas/INN22de27 deagostode2012.pdf. Acessado em 29 de ago. 2017a.

INSTRUÇÃONORMATIVAN²4,DE16DEDEZEMBRO DE 2005. Normas para produção, comercialização e utilização de mudas. Disponível em: http://www. agricultura.gov.br/assuntos/insumos-agropecuarios/ insumos-agricolas/sementes-e-mudas/publicacoessementes-e-mudas/INN24de16dedezembrode2005.pdf. Acessado em 29 de ago. 2017b.

INSTRUÇÃO NORMATIVAN ${ }^{\circ}$ 37, DE 5 DE SETEMBRO DE 2016. Critérios e procedimentos para o estabelecimento e manutenção do status fitossanitário relativo à praga do cancro cítrico, Xanthomonas citri subsp. citri. Disponível em: http://www.agricultura.gov.br/assuntos/sanidadeanimal-e-vegetal/sanidade-vegetal/arquivos-prevencao/ IN37 2016Cancroctrico.pdf/view. Acessado em 29 de ago. $2017 \mathrm{c}$.

INSTRUÇÃONORMATIVAN ${ }^{\circ}$ 48, DE24DESETEMBRO DE 2013. Normas de Produção e Comercialização de Material de Propagação de Citros - Citrus spp, Fortunella spp, Poncirus spp, e seus híbridos, bem como seus padrões de identidade e de qualidade, com validade em todo o Território Nacional. Disponível em: http://www. agricultura.gov.br/assuntos/insumos-agropecuarios/ insumos-agricolas/sementes-e-mudas/publicacoessementes-e-mudas/INN48de24desetembrode2013.pdf. Acessado em 29 de ago. 2017d.

INSTRUÇÃO NORMATIVAN ${ }^{\circ}$ 53, DE 16 DEOUTUBRO DE 2008. Critérios e procedimentos para a realização dos levantamentos de Huanglongbing (HLB). Disponível em: http://www.agricultura.gov.br/assuntos/sanidadeanimal-e-vegetal/sanidade-vegetal/arquivos-prevencao/ IN53 2008HLB.pdf/view. Acessado em 29 de ago. 2017e.

INVENTÁRIO de árvores e estimativa da safra de laranja do cinturão citrícola de São Paulo e Triângulo/Sudoeste Mineiro: retrato dos pomares em março de 2018 / Fundo de Defesa da Citricultura, Araraquara-SP: Fundecitrus, 2018. 111p.

JESUS JUNIOR, W.C.; BASSANEZI, R.B. Análise da dinâmica e estrutura de focos da morte súbita dos citros. Fitopatologia Brasileira, Brasília, v.29, p.399-405, 2004.

KITTO, S.L. Commercial micropropagation. HortScience, Alexandria, v. 32 n.6, p.1012-1014, 1997. 
KOLLER, O.C. Citricultura: laranja, limão e tanterina. Porto Alegre: Rigel, 1994. 44p.

KOLLER, O.L.; SOPRANO, E.; COSTA, A.C.Z.; KOLLER, O.C.; YAMANISHI, O.K. Indução de floração e produção de frutos em laranjeira 'Shamouti'. Laranja, Cordeirópolis, v.21, n.2, p.307-325, 2000.

KRUEGER, R.R.; NAVARRO, L. Citrus germplasm resources. In: KHAN, I.A. (ed.). Citrus Genetics, Breeding and Biotechnology. Wallingford, CAB International, 2007. Cap.4, p.45-140.

KUBOTA, T.M.K.; MAGALHÃES, A.B.; SILVA, M.N.; VILLAS BOAS. P.R1, NOVELLI, V.M.; BASTIANEL, M.; SAGAWA, C.H.D.; CRISTOFANI-YALY, M.; MILORI, D. M. B. P. Laser-induced Fluorescence Spectroscopy (LIFS) for Discrimination of Genetically Close Sweet Orange Accessions (Citrus sinensis L. Osbeck). Applied Spectroscopy, v. 71, n.2, p. 203-214, 2017.

LARANJEIRA, F.F.; AMORIM, L.; BERGAMIN FILHO, A.; AGUILAR-VILDOSO, C.I.; COLETTA FILHO, H.D. Fungos, procariotos e doenças abióticas. In: MATTOS JR., D.; DE NEGRI, J.D.; PIO, R.M.; POMPEU JUNIOR, J. (Ed.). Citros. Campinas: Instituto Agronômico e Fundag, 2005. p. 679-727.

LATADO, R.R. Laranjas sanguíneas no Brasil. Ciencia \& Prática, v.15, n.57 (edição digital), 2016. Disponível em: http://www.gtacc.com.br/revista/57a-edicao/laranjassanguineas-no-brasil. Consultado em 10/08/2017.

LATADO, R.R.; TULMANN NETO, A.; ANDO, A.; IEMMA, A.F.; POMPEU JUNIOR, J.; FIGUEIREDO, J.O.; PIO, R.M.; MACHADO, M.A.; NAMEKATA, T.; CERAVOLO, L.; ROSSI, A.C. Mutantes de laranja 'Pêra' com número reduzido de sementes, obtidos através de mutações induzidas. Revista Brasileira de Fruticultura, Jaboticabal, v.23, n.2, p.339-344, 2001.

LIN, C.Y.; WU, M.L.; SHEN, T.L.; YEH, H.H.; HUNG, T.H. Multiplex detection, distribution, and genetic diversity of Hop stunt viroid and Citrus exocortis viroid infecting citrus in Taiwan. Virology Journal, v.12:11, 2015.

LOCONSOLE, G.; SAPONARI, M.; SAVINO, V. Development of real-time PCR based assays for simultaneous and improved detection of citrus viruses. European Journal of Plant Pathology, Berlin, v.128, n.2, p.251-259, 2010.
MACCHERONI, W.; ALEGRIA, M.C.; GREGGIO, C.C.; PIAZZA, J.P.; KAMLA, R.F.; ZACHARIAS, P.R.A.; BAR-JOSEPH, M.; KITAJIMA, E.W.; ASSUMPÇÃO, L.C.; CAMAROTTE, G., \& other authors. Identification and genomic characterization of a new virus (Tymoviridae family) associated with citrus sudden death disease. Journal of Virology, Washington, v.79, n.5, p.3028-3037, 2005 .

MAIA, E.; SIQUEIRA, D.L.; CARVALHO, S.A.; PETERNELLI, L.A.; LATADO, R.R. Aplicação da análise espacial na avaliação de experimentos de seleção de clones de laranjeira Pêra. Ciência Rural, Santa Maria, v.43, n.8, p.8-14, 2013.

MATTOS JR., D.; QUAGGIO, J.A.; CARVALHO, S.A.; ABREU, M.F. Substrato para produção de mudas cítricas em recipientes: caracterização da toxicidade de boro. Laranja, Cordeirópolis, v.16, n.1, p.255-262, 1995.

MELLONI, R.; CARDOSO, E. J. B. N. Quantificação de micélio extracelular de fungos micorrízicos arbusculares em plantas cítricas. II. Comparação entre diferentes espécies cítricas e endófitos. Revista Brasileira de Ciência do Solo. Viçosa, v. 23, p. 59-67, 1999.

MILORI, D. M. B. P.; RAUNAUD, M.; VILLAS-BOAS, P.R.; VENÂNCIO, A.L.; MOUNIR, S.; BASSANEZI, R.B.; REDON, R. "Identification of Citrus Varieties Using Laser-Induced Fluorescence Spectroscopy (LIFS)". Computers and Electronics in Agriculture, v.95, p.11-18, 2013.

MIRANDA, M.P.; SANTOS, F.L.; FELIPPE, M.R.; MORENO, A.; FERERES, A. Effect of UV-Blocking Plastic Films on Take-Off and Host Plant Finding Ability of Diaphorina citri (Hemiptera: Liviidae). Journal of Economic Entomology, v. 108, p. 245-251, 2015.

MIRANDA, M.P; YAMAMOTO, P.T.; GARCIA, R.B.; LOPES, J.P.A.; LOPES, J.R.S. Thiamethoxam and imidacloprid drench applications on sweet orange nursery trees disrupt feeding and settling behavior of Diaphorina citri (Hemiptera: Liviidae). Pest Management Science, v. 72, p. 1785-1793, 2016.

MORAES FILHO, R.M.; JIMENEZ, H.J.; VALOIS, A.V.; MUSSER, M.R.S.; SILVA, M.M.; SILVA, E.F.; MARTINS, L.S.S. Variabilidade genética em genótipos da coleção de germoplasma de Citrus, do Instituto Agronômico de Pernambuco Brejão-PE, por meio de marcadores moleculares ISSR. Citrus Research $\&$ Technology, Cordeirópolis, v.32, n.2, p.67-76, 2011. 
MOREIRA, S.; SALIBE, A.A. Importância, produção e seleção de clones nucelares de citros. Ciência e Cultura, v.17, p.187, 1966. (Reunião Anual da SBPC - Resumo n.186).

MOURÃO FILHO, F.A.A.; DIAS, C.T.S.; SALIBE, A.A. Efeito da composição do substrato na formação de mudas de laranjeira Pêra. Scientia Agricola, Piracicaba, v.55, n.1, p.35-42, 1998.

MOURÃO FILHO, F.A.A.; GIRARDI, E.A.; COUTO, H.T.Z. 'Swingle' citrumelo propagation by cuttings for citrus nursery tree production or inarching. Scientia Horticulturae, New York, v.120, p.207-212, 2009.

MÜLLER, G.W.; TARGON, M.L.N.; MACHADO, M.A. Trinta anos de uso do clone pré- imunizado Pêra IAC na citricultura paulista. Laranja, Cordeirópolis, v.20, p.399408, 1999.

MÜLLER, G.W; REZENDE, J.A.M. Preimmunization: applications and perspectives in virus disease control. In: NAQVI, S.A.M.H. (Ed.). Diseases of Fruits and Vegetables, Dordrecht: Kluwer Academic Publishers, 2004. p.361-39.

MURASHIGE, T.; BITTERS, W.P.; RANGAN, T.S.; NAUER, E.M.; ROISTACHER, S.N.; HOLLIDAY, B.P. A technique of shoot apex grafting and its utilization towards recovering virus-free citrus clones. HortScience, Alexandria, v.7, p.118-119. 1972.

MURCIA, N.; BERNAD, L.; SERRA, P.; BANIHASHEMIAN, S.M.; DURAN-VILA, N. Molecular and biological characterization of natural variants of Citrus dwarfing viroid. Archives of Virology, v.154, p.13291334, 2009.

NADORI, E. B. Nadorcott mandarin; a promising new variety. In: INTERNATIONAL CITRUS CONGRESS, 10, 2004, Agadir, Marrocos. Proceedings... Agadir, Marruecos, International Society of Citriculture. v.1, p.356-359. 2004.

NASCIMENTO, L. M.; POMPEU JR, J.; DE NEGRI, J.D.; ZARA, F.A; CHIGNOLLI, F.C . Laranja Charmute de Brotas: promissora variedade tardia. Laranja, Cordeirópolis, v. 26, n.1, p. 69-75, 2005.

NAVARRO, L.; ROISTACHER, C.N.; MURASHIGE, T. Improvement of shoot-tip grafting in vitro for virus-free citrus. Journal American Society for Horticultural Science, Alexandria, v.100, n.5, p.471-479, 1975.
NEAL, C.A.; HENLEY, R.W. Water use and runoff comparisons of greenhouse irrigation systems. Proceedings of the Florida State Horticultural Society, Tallahassee, v.105, n.1, p.191-194, 1992.

NEJAT, N.; VADAMALAI, G.; DICKINSON, M. Spiroplasma citri: a wide range phytopathogen. Plant Pathology Journal, London, v.10, n.2, p.46-56, 2011.

NEVES, M. F.; TROMBIN, V. G.; MILAN, P.; LOPES, F. F.; CRESSONI,F.; KALAKI, R. O retrato da citricultura brasileira, São Paulo:CitrusBR, 2010. 138p.

NOVELLI, V.M., TAKITA, M.A.; MACHADO, M.A. Identification and Analysis of Single Nucleotide Polymorphisms (SNPs) in Citrus. Euphytica, Wageningen, n.3, v.138, p.227-237. 2004.

NOVELLI, V.M.; CRISTOFANI, M.; SOUZA, A.A.; MACHADO, M.A. Development and characterization of polymorphic microsatellite markers for the sweet orange (Citrus sinensis L. Osbeck). Genetics and Molecular Biology, v.29, n.1, p.90-96, 2006.

NYSSEN, D.; FANTINI, G.R.; PAZZETTI, L.H.; CARVALHO, S.A. Eficiência na fertirrigação em borbulheira de citros sob telado com uso de sistema de barra móvel automatizada. In: $10^{\circ}$ CONGRESSO INTERINSTITUCIONALDE INICIAÇÃOCIENTÍFICA, 10, Campinas, 2016. Resumos.... IAC, Campinas, 2016. Resumo ${ }^{\circ} 16144$.

OLIVEIRA, A. A. R.; WEBER, O. B.; SILVA, A. C. G. M. Micorrização e crescimento de porta-enxertos de citros em função de inóculos micorrízicos vesículoarbusculares. Pesquisa Agropecuária Brasileira, Brasília, v.27, n.9, p.1049-1056, 1992.

OLIVEIRA, E.R.M.; RODRIGUES, M.J.SILVA; DANTAS, A.C.V.L; SOARES FILHO, W.SANTOS; GIRARDI, E.A. Indolbutiric acid effect on the rooting and plant growth of 15 citrus rootstocks propagated by cuttings. Citrus Research \& Technology, Cordeirpópolis, v.35, n.1, p.35-43, 2014.

OLIVEIRA, I.V.M., DAMIÃO-FILHO, C.F; CARVALHO, S.A. Enxertia em citros por substituição de ápice caulinar. Revista Brasileira de Fruticultura, Jaboticabal, v.24, n.3, p.744-747. 2002.

OLIVEIRA, R.P.; GONÇALVES, A.S.; SCIVITTARO, W.B.; NAKASU, B.H. Tecnologias para produção de frutas cítricas sem sementes: escolha de cultivares e planejamento do pomar. Pelotas, Embrapa Clima Temperado, 4p. 2005 (Comunicado Técnico, 113). 
OLIVEIRA, R.P.; SCIVITTARO, W.B.; VARGAS, J.R. Fita plástica e fita degradável na enxertia de citros. Revista Brasileira de Fruticultura, Jaboticabal, v.26, n.2, p.564566, 2004.

OLIVEIRA, R.P.; UENO, B.; SCIVTTARO, W.B.; CASTO, L.A.S.; CAMPOS, A.D., SCHUCH, J.L.D. Dekopon - híbrido sem sementes de citros, com pescoço saliente e elevado conteúdo de açúcares. Pelotas: Embrapa Clima Temperado, Novembro 2012. 2p. (Folder técnico).

PACHECO, C.A.; AZEVEDO, F.A.; BARROS, V.N.P.; CRISTOFANI-YALY, M.; VERRUMA-BERNARDI, M.R. Fremont - IAC 543: tangerine with potential for the brazilian market. Revista Brasileira de Fruticultura, Jaboticabal, v.39, n.Spe. (e-436), 2017. DOI 10.1590/010029452017436.

PAIVA, L.V.; CARVALHO, S.A. Alternativa para promoção de crescimento in vivo de microenxertos de citros. Pesquisa. Agropecuária Brassileira, Brasília, v.28, n.9, p.1085-1099, 1993.

PAIVA, L.V.; SOUZA, M.; LOPES, M.A.; PAIVA, E. Identificação e isolamento de proteínas exclusivas de plantas com declínio dos citros. Pesquisa Agropecuária Brasileira, Brasília, v.32, n.5, p.559-564, 1997.

PAROLIN, L.G.; GIRARDI, EA.; STUCHI, E.S.; COSTA, D. P.; JESUS, C.A.S.; REIFF, E.T.; SEMPIONATO, O.R.; DOBRE, R.P.; MINGOTTE, F.L.C.; PASSOS, O.S.; SOARES FILHO, W.S. Produção de mudas de citros em viveiro protegido, utilizando diferentes combinações de copa e de porta-enxerto. Cruz das Almas-BA: Embrapa Mandioca e Fruticultura, 2017 (Boletim de Pesquisa e Desenvolvimento 84).

PARRA, J.R.P.; LOPES, J.R.S.; ZUCCHI, R.A.; GUEDES, J.V.C. Biologia de Insetos-praga e vetores. In: MATTOS JR., D; DE NEGRI, J.D.; PIO, R.M.; POMPEU Jr., J. (Ed.). Citros. Campinas: Instituto Agronômico; Fundag, 2005. p. 655-687.

PEREIRA, B.F.F.; CARVALHO, S.A. Métodos de forçamento de borbulhas e aplicação de cianamida hidrogenada para produção de mudas de laranja 'Valência' sobre citrumelo 'Swingle' em viveiro telado. Revista Brasileira de Fruticultura, Jaboticabal, v.28, n.1.p.151155, 2006.

PERIN, J.R.; CARVALHO, S.A. MATTOS JR., D. Caracterização Agronômica de Matrizes do Centro de Citricultura Sylvio Moreira. In: CONGRESSO BRASILEIRO DE FRUTICULTURA, 15, Poços de Caldas, 1998. Resumos... SBF, Poços de Caldas, 1998. p.248.
PERIN, J.R.; CARVALHO, S.A.; MATTOS JR., D.; CANTARELLA, H. Efeitos de substratos e doses de fertilizante de liberação lenta no teor de clorofila e desenvolvimento vegetativo do limoeiro 'Cravo' em tubetes. Laranja, Cordeiróplis, v. 20, n. 2, p. 463-476, 1999.

PINA, J.A.; CHOMÉ, P.; VIVES, M.C.; NAVARRO, L. The citrus nursery tree certification program in Spain. Acta Horticulture, v.1065, p.745-751, 2015.

PIO, R. M.; FIGUEIREDO, J. O.; STUCHI, E.S.; CARDOSO, S.A.B. Variedades Copas. In: MATTOS JR., D., DE NEGRI, J.D.; PIO, R.M.; POMPEU JR., J. (Eds). Citros. Campinas: Instituto Agronômico e Fundag, p.429-447, 2005.

POMPEU JR., J. Porta enxertos. In: MATTOS JR., D.; DE NEGRI, J.D.; PIO, R.M.; POMPEU JR., J. (Ed.). Citros. Campinas: Instituto Agronômico; Fundag, 2005. p. 61-104.

POMPEU JR., J.; BLUMER, S. Variedades porta-enxertos. $\mathbf{2 3}^{\circ}$ Curso de Citricultura. Centro de Citricultura, Cordeirópolis, julho de 2016. Mídia digital.

POMPEU JR., J.; BLUMER, S. Performance de citrumelos F80 no Estado de São Paulo. Laranja, Cordeirópolis, v. 26, n.1, p. 77-85, 2005.

PORTARIA MAPA No 291, DE 23 DE JULHO DE 1997. Normas sobre exigências, critérios e procedimentos, a serem adotados pela Campanha Nacional de Erradicação do Cancro Cítrico CANECC, em áreas contaminadas pela doença e naquelas que venham a ser afetadas. Disponivel em: http://www.aged.ma.gov.br/files/2017/06/PortariaMAPA-n-\%C2\%BA-291-CANNEC.pdf. Acessada em 25 ago. 2017.

PORTO, S.M.C.; ARCIDIACONO, C.; ANGUZZA, U.; CASCONE, G. Development of an information system for the traceability of citrus-plant nursery chain related to the Italian National Service for Voluntary Certification. Agricultural Engineering International: CIGR Journal, v.16, p. 208-216, 2014.

PORTO, S.M.C.; ARCIDIACONO, C.; CASCONE, G. Developing integrated computer-based information systems for certified plant traceability: Case study of Italian citrus-plant nursery chain. Biosystems Engineering, v.109, n.2, p.120-129, 2011. 
PRADO, R.M.; ROZANE, D.E.; CAMAROTTI, G.S.; CORREIA, M.A.R.; NATALE, W.; BARBOSA, J.C.; BEUTLER, A.N. Nitrogênio, fósforo e potássio na nutrição e na produção de mudas de laranjeira 'Valência', enxertada sobre citrumeleiro 'Swingle'. Revista Brasileira de Fruticultura, Jaboticabal, v.30, p.812-817, 2008.

PRATTI, P.; MOURÃO FILHO, F.A.A.; DIAS, C.T.S.; SCARPARE FILHO, J.A. Estaquia semi-lenhosa: um método rápido e alternativo para a produção de mudas de lima ácida 'Tahiti'. Scientia Agricola, Piracicaba, v.56, n.1, p.185-190, 1999.

PRUDENTE, R.M.; SILVA, L.M.S. da; CUNHA SOBRINHO, A.P. da. Comportamento da laranjeira 'Pêra' sobre cinco porta-enxertos em ecossistema de Tabuleiros Costeiros, Umbaúba - SE. Revista Brasileira de Fruticultura, Jaboticabal, v.26, n.1, p.101-112, 2004.

QUARENTENÁRIO IAC. Disponível em: http://www. iac.sp.gov.br/areasdepesquisa/quarentenario/quarentena. php (Acessado em 31/07/2017).

RAMOS, Y.C.; STUCHI, E.S.; GIRARDI, E.A.; LEÃO, H.C. de; GESTEIRA, A. da S.; PASSOS, O.S.; SOARES FILHO, W. dos S. Dwarfing Rootstocks for 'Valência' Sweet Orange. Acta Horticulturae, v.1, p.351-354, 2015.

RESOLUÇÃO SAA- 10, DE 20 FEVEREIRO DE 2017. Delimita e oficializa todo o território do Estado de São Paulo como área sob Sistema de Mitigação de Risco, relativo à praga do cancro cítrico, Xanthomonas citri subsp. citri e institui procedimentos fitossanitários. Disponivel em: https:/www.defesa.agricultura.sp.gov.br/ legislacoes/resolucao-saa-10-de-20-02-2017,1093.html. Acessada em 25 ago. 2017.

REZENDE, C.F.A.; BARBOSA, J.M.; BRASIL, E.P.F.; LEANDRO, W.M.; FRAZÃO, J.J. Normas Dris para portaenxertos limão Cravo e citrumelo Swingle. Fronteiras: Journal of Social, Technological and Environmental Science, Anápolis, v.6, n.1, p.219-231, 2017.

REZENDE, L. de P.; AMARAL, A.M.; CARVALHO, S.A.; SOUZA, M. de. Volume de substrato e superfosfato simples na formação do limoeiro 'Cravo' em vasos. I Efeitos no crescimento vegetativo. Laranja, Cordeirópolis, v. 15, n.2, p.165-178, 1995.

RIBEIRO, M.D.; FERRAREZI, R.S.; TESTEZLAF, R. Validação de parâmetros operacionais para o manejo de mesas de subirrigação. Horticultura Brasileira, Brasília, v.35, n.4, p.1-7, 2017.
RIBEIRO, R.V.; ESPINOZA-NÚÑEZ, E.; POMPEU JUNIOR, J.; MOURÃO FILHO, F.A.A.; MACHADO, E.C. Citrus rootstocks for improving the horticultural performance and physiological responses underconstraining environments. In: AHMAD P., WANI, M. R.; AZOOZ, M.M.; TRAN, L.S.P. (eds.), Improvement of Crops in the Era of Climatic Changes, New York, v.1, p.1.37, 2014.

RIZZO, D., MATERAZZI, A.; STEFANI, L.; PANATTONI, A.; PIERRO, R.; DE BELLIS, L.; LUVISI, $A$. The occurrence of viruses and viroids in ornamental citrus mother plants in Tuscany (Central Italy). Crop Protection, London, v.102, n.1, p.137-140, 2017.

RODRIGUES, J.C.V.; OLIVEIRA, C.A.L. de. Ácaros fitófagos dos citros. In: MATTOS JR., D.; DE NEGRI, J.D.; PIO, R.M.; POMPEU JR., J. (Ed.). Citros. Campinas: Instituto Agronômico e Fundag, 2005. p. 679-727.

RODRIGUES, M.J.S.; LEDO, C.A.S.; GIRARDI, E.A.; ALMEIDA, L.A.H.; SOARES FILHO, W.S. Caracterização de frutos e propagação de porta-enxertos híbridos de citros em ambiente protegido. Revista Brasileira de Fruticultura, Jaboticabal, v. 37, n. 2, p. 457-470, 2015.

RODRIGUES, M.J.S.; OLIVEIRA, E.R.M.; GIRARDI, E.A.; LEDO, C.A.S.; SOARES FILHO, W.S. Produção de mudas de citros com diferentes combinações copa e porta-enxerto em viveiro protegido. Revista Brasileira de Fruticultura, Jaboticabal, v. 38, n. 1, p. 187-201, 2016.

ROISTACHER, C.N. Graft-transmissible diseases of citrus, handbook for detection and diagnosis. Rome: IOCV, FAO, 1991. 286p.

ROLFS, P.H.; ROLFS, C. A muda de citrus: pedra angular da industria citricola. Viçosa: Oficinas graphicas da estatistica, 1931. 126 p.

ROMEIRO, S.; CARVALHO, S.A.; AGUILARVILDOSO, C.; BLUMER, S. Embalagem e tratamento químico na conservação de ramos porta-borbulhas de laranjeira Natal armazenados em câmara fria. Laranja, Cordeirópolis, v.22, n.2, p.425-433. 2001.

ROY, A.; FAYAD, A.; BARTHE, G.; BRLANSKY, R.H. A multiplex polymerase chain reaction method for reliable, sensitive and simultaneous detection of multiple viruses in citrus trees. Journal of Virological Methods, v.129, n.1, p.47-55, 2005. 
RUIZ-RUIZ, S.; AMBRÓSA, S.; VIVES, M.C.; NAVARRO, L.; MORENO, P.; GUERRI, J. Detection and quantitation of Citrus leaf blotch virus by TaqMan realtime RT-PCR. Journal of Virological Methods, v.160, n.1, p.57-62, 2009.

SALEH,B.;ALLARIO, T.; DAMBIER, D.; OLLITRAULT, P.; MORILLON, R. Tetraploid citrus rootstocks are more tolerant to salt stress than diploid. Compets Rendus Biologies, v.331, n.9, p.703-710, 2008.

SALVA, R. A. Distribuição de Phytophthora spp. em viveiros de mudas cítricas no Estado de São Paulo. 2004. Dissertação (Mestrado em Produção Vegetal). Universidade Estadual Paulista-UNESP, Faculdade de Ciências Agrárias e veterinárias, Jaboticabal, 2004.

SALVADOR, C.A.; FERRAREZI, R.S.; BARRETO, C.V.G.; TESTEZLAF, R. Method to evaluate the efficiency of manual overhead irrigation in citrus rootstock liner production. Engenharia Agrícola, Jaboticabal, v.36, n. 4, p.724-735, 2016.

SANCHES, A.L; FELIPPE, M.R.; UEHARA-CARMO, A.; RUGNO, G.R.; YAMAMOTO, P.T. Eficiência de inseticidas sistêmicos, aplicados em mudas cítricas, em préplantio, no controle de Diaphorina citri (Kuwayama) (Hemiptera: Psyllidae). BioAssay, Santo Antônio de Goiás, v.4, n.1, p.1-7, 2009.

SANKAR, T.G.; GOPI, V.; DEEPA, B.; GOPAL, K. Genetic diversity analysis of sweet orange (Citrus sinensis osbeck) varieties/clones through RAPD markers. International Journal of Current Microbiological and Applied Science, Tamilnadu, v.3, n.4, p.75-84, 2014.

SANTANA-VIEIRA, D.D.S.; MILORI, D.M.B.P.; VILLAS-BOAS, P.R.; SILVA, M.F.; SANTOS, M.G.; GAIOTTO, F.A. SOARES FILHO, W.S.; GESTEIRA, A.S. Rapid Differentiation of Closely Related Citrus Genotypes by Fluorescence Spectroscopy. Advances in Bioscience and Biotechnology, v.5, n.11, p.903-914, 2014.

SANTOS, J.M.; CAMPOS, A.S.; AGUILAR-VILDOSO, C.I. Nematoides dos citros. In: MATTOS JR., D. de; DE NEGRI, J.D.; PIO, R.M.; POMPEU JR., J. (Ed.). Citros. Campinas: Instituto Agronômico; Fundag, 2005. p.606627.

SANTOS, M.G.; SOARES FILHO, W.S.; GIRARDI, E.A.; GESTEIRA, A.S.; PASSOS, O.S.; FERREIRA, C. F. Initial horticultural performance of nine 'Persian' lime selections grafted onto Swingle citrumelo. Scientia Agricola, Piracicaba, v. 73, n. 2, p. 109-114, 2016.
SÃO PAULO (Estado). Coordenadoria de Defesa Agropecuária. Portaria CDA n. 5, de 02 de fevereiro de 2005a. Estabelece normas de Medidas de Defesa Sanitária Vegetal e Certificação de Conformidade Fitossanitária de Mudas Cítricas no Estado de São Paulo. Diário Oficial do Estado de São Paulo. São Paulo, SP, 04 fev. 2005a. Seção I, n. 115 (24), p. 16-17.

SÃO PAULO (Estado). Coordenadoria de Defesa Agropecuária. Portaria CDA n. 23, de 13 de junho de 2005b. Estabelece medidas de defesa sanitária vegetal aplicáveis ao cadastro de Plantas Matrizes e de Borbulheiras de citros no Estado de São Paulo. Diário Oficial do Estado de São Paulo. São Paulo, SP, 14 jun. 2005b. Seção I, n. 115 (109), p. 14-15.

SÃO PAULO (Estado). Coordenadoria de Defesa Agropecuária. Portaria CDA n. 17, de 05 de abril de 2018a. Estabelece no Estado de São Paulo, normas para o cadastramento de viveiro para produção de muda de citros, de depósito de muda de citros e de Engenheiro Agrônomo - Responsável Técnico e institui normas técnicas de Defesa Sanitária Vegetal para produção, comércio, transporte e utilização de muda de citros. Diário Oficial do Estado de São Paulo. São Paulo, SP, 06 abr. 2018a. Seção I, n. 128 (63), p. 27-28.

SÃO PAULO (Estado). Coordenadoria de Defesa Agropecuária. Portaria CDA n. 18, de 05 de abril de 2018b. Estabelece no Estado de São Paulo, normas para cadastramento de Planta Básica, Planta Matriz e Planta fornecedora de sementes de Citros e de Engenheiro Agrônomo - Responsável Técnico e institui normas técnicas de Defesa Sanitária Vegetal sobre manutenção, produção, comércio, transporte e uso. Diário Oficial do Estado de São Paulo. São Paulo, SP, 06 abr. 2018b. Seção I, n. 128 (63), p. 28-30.

SÃO PAULO (Estado). Coordenadoria de Defesa Agropecuária. Portaria CDA n. 19, de 05 de abril de 2018c. Estabelece no Estado de São Paulo, normas para o cadastramento de borbulheira de citros e de Engenheiro Agrônomo - Responsável Técnico e institui normas técnicas de Defesa Sanitária Vegetal para produção, comércio, transporte e utilização de borbulha de planta de citros. Diário Oficial do Estado de São Paulo. São Paulo, SP, 06 abr. 2018c. Seção I, n. 128 (63), p. 30-31. 
SÃO PAULO (Estado). Coordenadoria de Defesa Agropecuária. Portaria CDA n. 20, de 05 de abril de 2018d. Estabelece no Estado de São Paulo a metodologia para coleta de amostra em planta básica, planta matriz, planta fornecedora de sementes, borbulheira, viveiro e depósito de muda de planta de citros, para análise laboratorial de fitossanidade. Diário Oficial do Estado de São Paulo. São Paulo, SP, 06 abr. 2018d. Seção I, n. 128 (63), p. 31.

SARMIENTO, A.I.P; SCHWARZ, S. F.; SOUZA, P.V.D. Condiciones de cultivo de la planta matriz y uso del ácido indolbutírico en la propagación del mandarino 'Sunki' por estaquilla. Revista Brasileira de Fruticultura [online], Jaboticabal, v. 38, n.2, e-334, 2016. DOI 10.1590/010029452016334.

SAVAGE, E. M.; GARDNER, F.E. The origin and history of Troyer and Carrizo citranges. The Citrus Industry, Bartow, v.46, n.2, p.5.7, 1965.

SCHINOR, E. H.; SIVIERO, A.; CRISTOFANI-YALY, M.; MARENGO, S.; POMPEU JUNIOR, J.; MACHADO, M. A. Caracterização agronômica e molecular de acessos de Citrus sunki do banco de germoplasma de citros do Centro APTA Citros Sylvio Moreira. Citrus Research \& Technology, Cordeirópolis, v.32, n.1, p.27-37, 2011.

SCHINOR, E.H.; NASCIMENTO, A.L.; BARROS, V.L.N.P.; M. BASTIANEL; AZEVEDO, F.A.; CRISTOFANI-YALY, M. Atributos de frutos e crescimento vegetativo de porta-enxertos de citrandarins em viveiro. Citrus Research \& Technology, Cordeirópolis, v.36, n.1, p. 27-35, 2015.

SEN, S.; DHAWAN, V. Development of a Highly Efficient Micropropagation Method for the Citrus Rootstock 'Swingle' Citrumelo [Poncirus trifoliate (L.) Raf. $\times$ C. paradise McFaden]. International Journal of Fruit Science, Oxford, v.10, n.1, p.65-78, 2010.

SERRANO, L.A.L.; MARINHO, C.S.; CARVALHO, A.J.C.; MONNERAT, P.H. Efeitos de sistemas de produção e doses de adubo de liberação lenta no estado nutricional de porta enxerto cítrico. Revista Brasileira de Fruticultura, Jaboticabal, v.26, n.3 p.524-528, 2004.

SETIN, D. Atual Banco de Sementes e Sistema de Produção de Mudas de Citros no Estado de São Paulo. $11^{\circ}$ Dia do Porta-enxerto. Centro de Citricultura, Cordeirópolis, março de 2017. Disponivel em: https:// ccsm.br/eventos/dia-porta-enxerto/. Acessado em 03, abr. 2017.
SETIN, D.W.; CARVALHO, S.A.; MATTOS JR., D. Crescimento inicial e estado nutricional da laranjeira 'Valência' sobre porta-enxertos múltiplos de limoeiro 'Cravo' e citrumeleiro 'Swingle'. Bragantia, CampinasSP, v.68, n.2, p.397-406, 2009.

SETIN, D.W.; CARVALHO, S.A.; MATTOS JR., D. Recipientes e substratos à base de fibra de coco na produção de mudas de laranjeira 'Valência' sobre limoeiro 'Cravo'. Laranja, Cordeirópolis, v. 26, n.2, p.337-348, 2005.

SHÄFER, G.; BASTIANEL, M.; DORNELLES, A.L.C. Diversidade genética em porta-enxertos cítricos baseada em marcadores moleculares RAPD. Ciência Rural, Santa Maria, v.34, n.5, p.1437-42, 2004.

SHARMA. S.; PRAKASH, A.; TELE, A. In vitro propagation of Citrus rootstocks. Notulae Botanicae Horti Agrobotanici Cluj-Napoca, Clausemburgo, v.37, n.1, p.84-88, 2009.

SILVA, L.F.C.; CARVALHO, S.A. Germinação da semente de porta-enxertos de citros em função da presença do tegumento e sua orientação no substrato. Laranja, Cordeirópolis, v. 28, n.1, p.47-59, 2007.

SIQUEIRA, D.L., VASCONCELLOS, J.F.F.; DIAS, D.C.F.S.; PEREIRA, W.E. Germinação de sementes de porta-enxertos de citros após o armazenamento em ambiente refrigerado. Revista Brasileira de Fruticultura, Jaboticabal, v.24, n.2, p.317-322. 2002.

SIVIERO, A.; FURTADO, E.L.; MACHADO, M.A. Avaliação de métodos de inoculação de Phytophthora parasitica em plântulas e plantas jovens de citros. Fitopatologia Brasileira, Brasilia, v. 27, p. 574-580, 2002.

SKARIA, M. A microbudding technique for biological Indexing and ultra-high density. Fourteenth IOCV Conference, 2000. Short Communications. p.411-413.

SOARES FILHO, W.S.; DIAMANTINO, M.S.A.S.; MOITINHO, E.D.B.; CUNHA SOBRINHO, A.P.; PASSOS, O.S. 'Tropical': uma nova seleção de tangerina 'Sunki'. Revista Brasileira de Fruticultura, Jaboticabal, v.24, n.1, p.127-132, 2002.

SOARES FILHO, W.S; SOUZA, U.; LEDO, C.A.A.; SANTANA, L.GL; PASSOS, O.S. Poliembrionia e potencial de obtenção de híbridos em citros. Revista Brasileira de Fruticultura, Jaboticabal, v.36, n.4, p.950956, 2014. 
SOLIS, C.; KHACHATRYAN, H.; BEESON, R. Profitability of citrus tree greenhouse production systems in Florida. Publication \#FE999. Gainesville: University of Florida Institute of Food and Agricultural Sciences, 2016. http://edis.ifas.ufl.edu/fe999. Accessado 16/05/2017.

SORRENTI, G.B.; FACHINELLO, J.C.; CASTILHOS, D.D.; BIANCHI, V.J.; MARANGONI, B. influência da adubação orgânica no crescimento de tangerineira cv clemenules e nos atributos químicos e microbiológicos do solo. Revista Brasileira de Fruticultura, Jaboticabal, v. 30, n. 4, p. 1129-1135, 2008.

SPANN, T.M.; FERGUSON, L. Commercial production of container-grown nursery trees, In: FERGUSON, L.; GRAFTON-CARDWELl, E.E. (Eds.), Citrus Production Manual. University of California, Richmond, 2014. pp.107-116.

STUCHI, E.S.; DONADIO, L.C.; SEMPIONATO, O.R. Performance of Tahiti lime on Poncirus trifoliata var. monstrosa Flying Dragon in four densities. Fruits, (Paris), Montepellier, v. 58, n.1, p. 13-17, 2003.

SUN, X.; MU, Q.; JIANG, D.; WANG, C.; WANG, X.C.; FANG, J.G. A new strategy employed for identification of sweet orange cultivars with RAPD markers. Genetics and Molecular Research, v.11, n. 3, p.2071-2080, 2012.

SUN, Y.L.; KANG, H.M.; HAN, S.H.; PARK, Y.C.; HONG, S.K. Taxonomy and phylogeny of the genus citrus based on the nuclear ribosomal DNA its region sequence Pakstan Journal of Botany, Karachi, v.47, n1., p.95-101, 2015.

TALLÓN, C.I.; PORRAS, I.; PÉREZ-TORNERO, O. Efficient propagation and rooting of three citrus rootstocks using different plant growth regulators. In Vitro Cellular \& Developmental Biology - Plant, v.48, n.5, p.488-499, 2012.

TAZIMA, Z. H.; LEITE JR., R. P. IAPAR-73: Nova cultivar precoce de laranja (Citrus sinensis (L.) Osb.) para o Estado do Paraná. In: CONGRESSO BRASILEIRO DE FRUTICULTURA, 16, 2000, Fortaleza. Anais... Fortaleza: Sociedade Brasileira de Fruticultura, 2000. CD-ROM.

TAZIMA, Z. H.; NEVES, C. S. V. J. ; YADA, I. F. U. ; LEITE JUNIOR, R. P. Crop production of 'Okitsu' satsuma mandarin on nine rootstocks in Southern Brazil. Acta Horticulturae, v.1065, p.367-371, 2015.
TAZIMA, Z.H.; NEVES, C.S.V.J.; YADA, I.F.U.; LEITE JUNIOR, R.P. Produção e qualidade dos frutos de clones de laranjeira 'Pera' no norte do Paraná. Revista Brasileira de Fruticultura, Jaboticabal, v.32, n.1, p. 189-195, 2010.

TEIXEIRA, P. D. T. L.; SCHAFER, G.; SOUZA, P. V. D.; TODESCHINI, A. Chemical scarification and initial development of citric rootstocks. Revista Brasileira de Fruticultura, Jaboticabal, v.31, n.3, p.865-871, 2009.

TESTEZLAF, R.; FERRAREZI, R.S. Irrigação subsuperficial. In: TESTEZLAF, R. (Ed.). Irrigação: Métodos, sistemas e aplicações. Campinas, SP: UNICAMP/FEAGRI, 215p. 2017. p.113-134. ISBN 97885-99678-10-7 e-book.

UPOV. Directrices para la ejecución del examen de la distinción, la homogeneidad y la estabilidad. Citrus L. - Grupo 2 Naranjo. Unión Internacional para la Protección de las Obtenciones Vegetales - UPOV, 40p. 2003.

VALLE, M.G. Impactos na citricultura paulista decorrentes da implementação de técnicas de produção de borbulhas e mudas sadias de citros. Laranja, Cordeirópolis, v.23, n.2, p.271-280, 2002.

VIDALAKIS, G; DA GRAÇA, J.V.; DIXON, W.N.; FERRIN, D.; KESINGER, M.; KRUEGER, R.R.; LEE, R.F.; MELZER, M.J.; OLIVE, J.; POLEK, M.; SIEBURTH, P.J.; WILLIAMS, L.L.; WRIGHT, G.C. Citrus Quarantine Sanitary and Certification Programs in the USA. Citrograph, Visalia, v.3, n.1, p.26-39, 2010.

VIVES, M.C.; GALIPIENSO, L.; NAVARRO, L.; MORENO, P.; GUERRI, J. Citrus Leaf Blotch Virus: A New Citrus Virus Associated with Bud Union Crease on Trifoliate Rootstocks. Fifteenth IOCV Conference - Other Viruses, p.205-212, 2002.

WANG, X.; DODDAPANENI, H.; CHEN, J.; YOKOMI, R.K. Improved Real-Time PCR Diagnosis of Citrus Stubborn Disease by Targeting Prophage Genes of Spiroplasma citri. Plant Disease, Ames, v.99, n.1, p.149154, 2015.

WANG, X.; ZHOU, C.; TANG, K.; ZHOU, Y.; LI, $Z$. A rapid one-step multiplex RT-PCR assay for the simultaneous detection of five citrus viroids in China. European Journal of Plant Pathology, Berlin, v.124, n.1, p.175-180, 2009.

WEBBER, H.J. Nursery methods. In: BATCHELOR, .L.D.; WEBBER, H.J. (Ed). The citrus industry, Berkley and Los Angeles: University of Californie Paress, 1948. v,2, Cap. 1, p.1-68. 
WEBER, O. B.; OLIVEIRA, A. A. R.; MAGALHÃES, A. F. J. Adubação orgânica e inoculação com Glomus etunicatum em porta-enxertos de citros. Revista Brasileira de Ciência do Solo. Viçosa, v.14, n.3, p. 321326, 1990.

WINKELMANN, T.; GEIER, T.; PREIL, W. Commercial in vitro plant production in Germany in 1984-2004. Plant Cell Tissue Organ Culture. Dordrecht, v. 86, p.319-327, 2006.
ZANETTI, M.; FERNANDES, C.; CAZETTA, J.O.; CORÁ, J.E.; MATTOS JUNIOR, D. Características físicas de substratos para a produção de mudas cítricas sob telado. Laranja, Cordeiropolis, v.24, n.2, p.519- 530, 2003.

ZORZO, V.; CARVALHO, S.A. Ocorrência de variações entre acessos homônimos das coleções de clones velhos e de clones nucelares do Banco Ativo de Germoplasma de Citros do IAC. Citrus Research \& Technology, Cordeirópolis, v.33, n.1, p.19-33, 2012. 